April 2003 • NREL/TP-510-33502

\title{
Highlights of Biopower Technical Assessment: State of the Industry and the Technology
}

R.L. Bain and W.A. Amos

National Renewable Energy Laboratory Golden, Colorado

M. Downing and R.L. Perlack Oak Ridge National Laboratory Oak Ridge, Tennessee

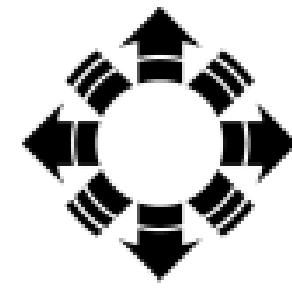

\section{NPEI}

National Renewable Energy Laboratory

1617 Cole Boulevard

Golden, Colorado 80401-3393

NREL is a U.S. Department of Energy Laboratory

Operated by Midwest Research Institute $\bullet$ Battelle $\bullet$ Bechtel

Contract No. DE-AC36-99-G010337 


\section{HIGHLIGHTS OF THE BIOPOWER TECHNICAL ASSESSMENT \\ State of the Industry and the Technology}

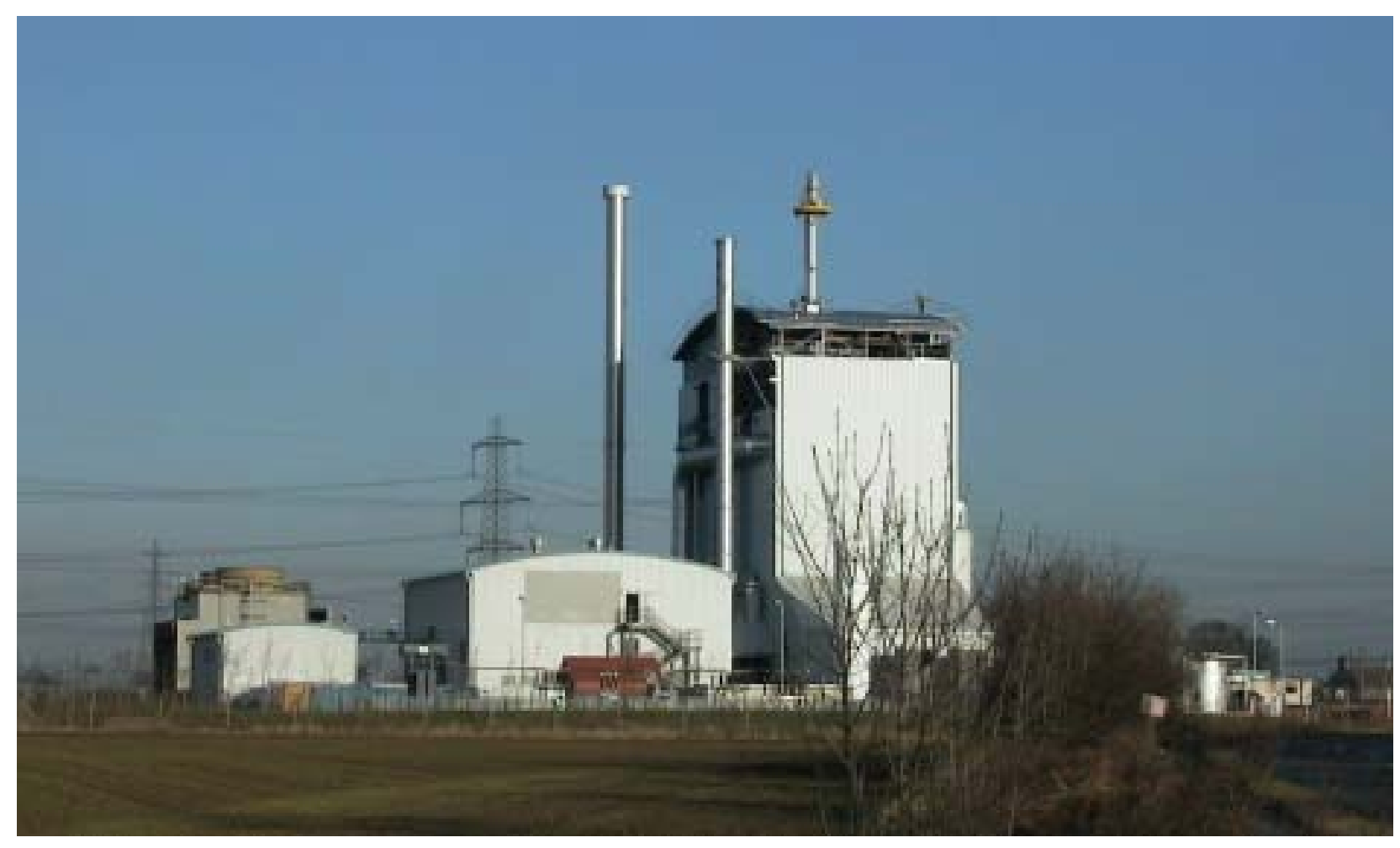

April 2003

Richard L. Bain and Wade A. Amos

National Renewable Energy Laboratory, Golden, Colorado

Mark Downing and Robert L. Perlack

Oak Ridge National Laboratory, Oak Ridge, Tennessee

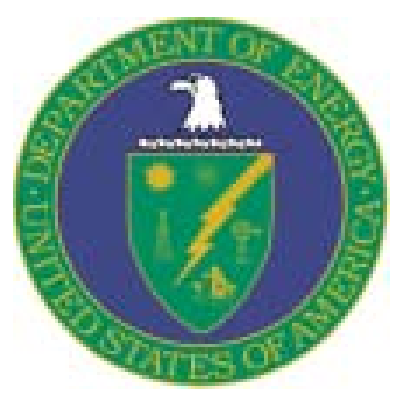




\section{NOTICE}

This report was prepared as an account of work sponsored by an agency of the United States government. Neither the United States government nor any agency thereof, nor any of their employees, makes any warranty, express or implied, or assumes any legal liability or responsibility for the accuracy, completeness, or usefulness of any information, apparatus, product, or process disclosed, or represents that its use would not infringe privately owned rights. Reference herein to any specific commercial product, process, or service by trade name, trademark, manufacturer, or otherwise does not necessarily constitute or imply its endorsement, recommendation, or favoring by the United States government or any agency thereof. The views and opinions of authors expressed herein do not necessarily state or reflect those of the United States government or any agency thereof.

Available electronically at http://www.osti.gov/bridge

Available for a processing fee to U.S. Department of Energy and its contractors, in paper, from:

U.S. Department of Energy

Office of Scientific and Technical Information

P.O. Box 62

Oak Ridge, TN 37831-0062

phone: 865.576 .8401

fax: 865.576.5728

email: reports@adonis.osti.gov

Available for sale to the public, in paper, from:

U.S. Department of Commerce

National Technical Information Service

5285 Port Royal Road

Springfield, VA 22161

phone: 800.553.6847

fax: 703.605.6900

email: orders@ntis.fedworld.gov

online ordering: http://www.ntis.gov/ordering.htm 


\section{Acknowledgments}

A significant portion of this study is excerpted from studies previously funded by the Department of Energy. The authors wish acknowledge the efforts of the authors of these studies in performing background research and preparing the reports that are so useful in this technical assessment.

Topic Source Authors

Barriers

“2001 EERE Strategic Program Review”

Lessons Learned

Lessons Learned

Technology

Characterizations

Environmental

Performance

Environmental

Performance

Policy

Policy
"Biomass Energy Production in California: The Case for a Biomass Policy Initiative"

"Lessons Learned from Existing Biomass Power Plants"

"Renewable Energy Technology

Characterizations"

"Green Power Fact Sheets"

"A Comparison of the Environmental Consequences of Power from Biomass, Coal, and Natural Gas"

"Biomass and Bioenergy in the United States"

"Incentives, Mandates, and Government

Programs for Promoting Renewable Energy"
Raymond Costello, DOE Paul Grabowski, DOE

Gregory Morris, Future Resources Associates, Inc.

George Wiltsee, Appel Consultants, Inc.

Kevin Craig, NREL

Kevin Comer, Antares Group

Margaret Mann, NREL

Kevin Comer, Anatares

Margaret Mann, NREL

Pamela Spath, NREL

Helena Chum, NREL Ralph P. Overend, NREL

Mark Gielecki, DOE-EIA

Fred Mayes, DOE-EIA

Lawrence Prete, DOE-EIA 


\section{CONTENTS}

\section{Page}

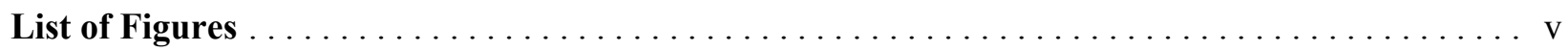

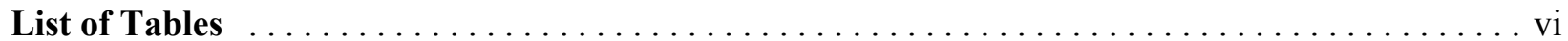

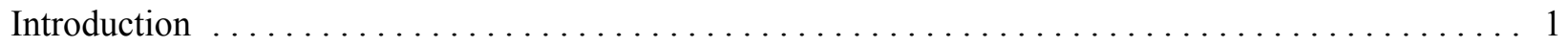

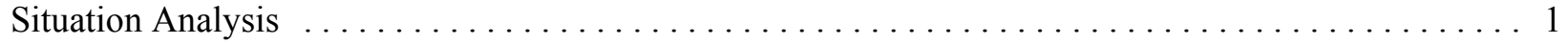

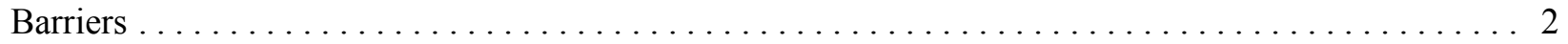

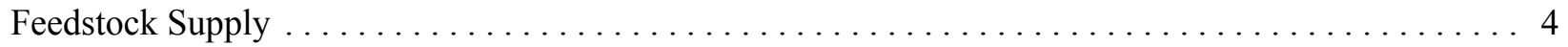

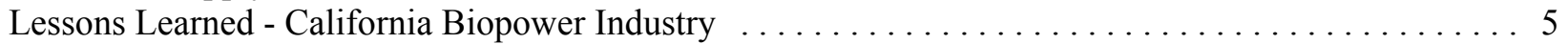

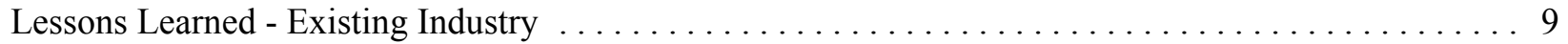

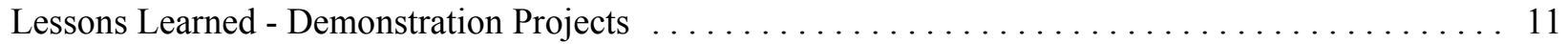

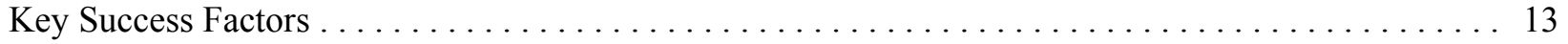

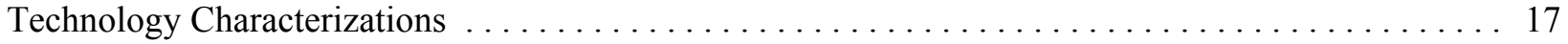

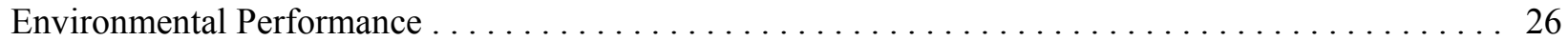

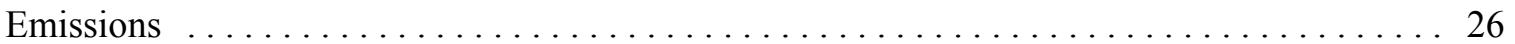

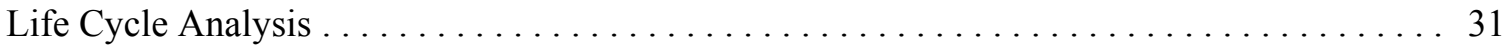

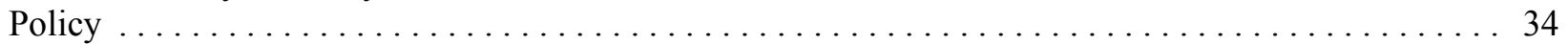




\section{List of Figures}

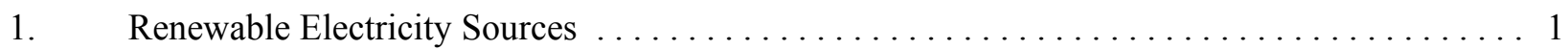

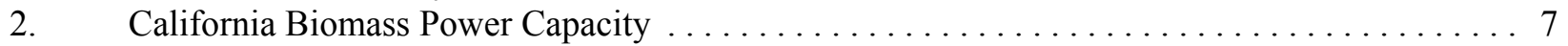

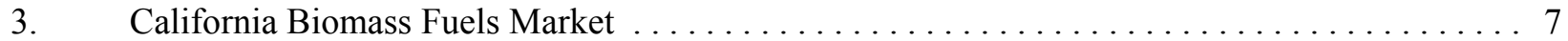

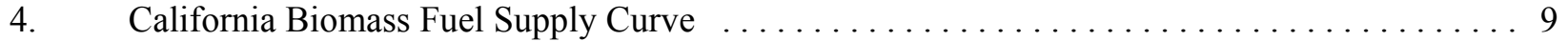

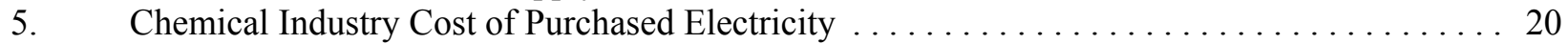

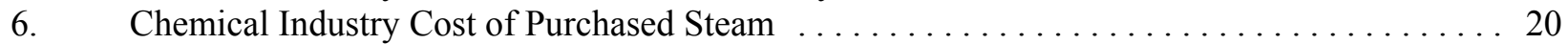

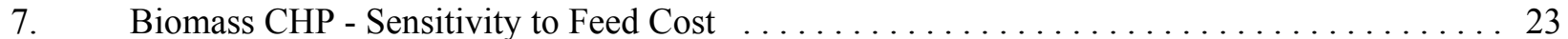

8. Biomass CHP - Effect of Plant Size on Cost of Electricity and Steam . . . . . . . . . . . . . 24

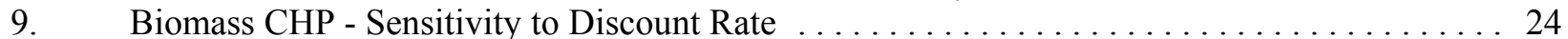

10. Biomass Combustion and Gasification CHP Impact of Tax Credit ................. 25

11. Biomass Cofiring CHP Incremental Costs, Impact of Tax Credit $\ldots \ldots \ldots \ldots \ldots \ldots \ldots \ldots$

12. Biomass Cofiring CHP - Impact of Tax Credit

on Return on Investment, Corporate Basis $\ldots \ldots \ldots \ldots \ldots \ldots \ldots \ldots \ldots$

13. NOx Emissions - Life Cycle Total and Plant Operating Emissions $\ldots \ldots \ldots \ldots \ldots \ldots \ldots \ldots$

14. Biomass Combustion - Potential for NOx Reduction $\ldots \ldots \ldots \ldots \ldots \ldots \ldots \ldots \ldots \ldots \ldots \ldots \ldots$

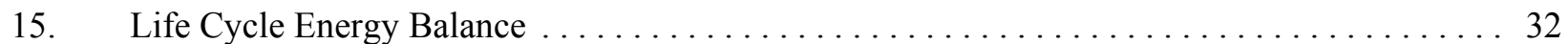

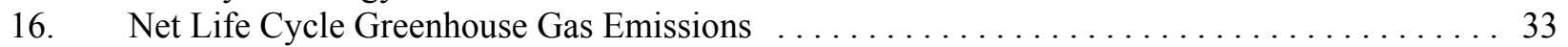

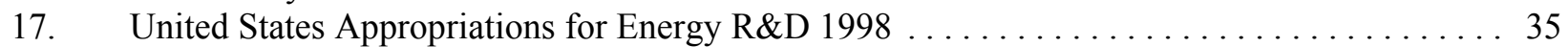

18. United States Appropriations for Renewables R\&D 1978 - $1998 \ldots \ldots \ldots \ldots \ldots \ldots \ldots$

19. United States Appropriations for Energy Efficiency R\&D 1978 - $1998 \ldots \ldots \ldots \ldots \ldots \ldots . \ldots 37$ 


\section{List of Tables}

1. Estimated Biomass Resources Available by State and Price $\ldots \ldots \ldots \ldots \ldots \ldots \ldots \ldots \ldots \ldots$

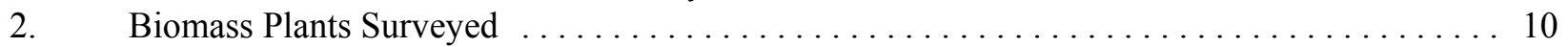

3. Key Drivers for Biomass CHP Systems $\ldots \ldots \ldots \ldots \ldots \ldots \ldots \ldots \ldots \ldots \ldots \ldots \ldots \ldots \ldots$

4. Key Success Factors, Relative to Coal and Natural Gas . . . . . . . . . . . . . . . . . . . 16

5. Biomass Plant Technical Performance . . . . . . . . . . . . . . . . . . . . . . . . . . . . 19

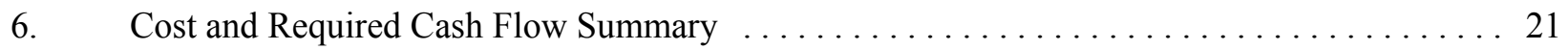

7. Direct Air Emissions from Wood Residue Facilities by Boiler Type

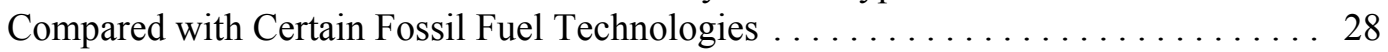

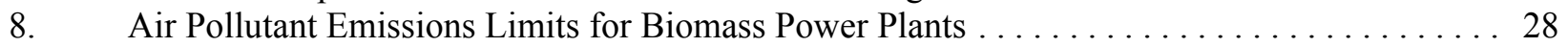

9. Texas Distributed Generation Certification Standards . . . . . . . . . . . . . . . . . . . . . . 29

10. Proposed California Distributed Generation Certification Standards . . . . . . . . . . . 29

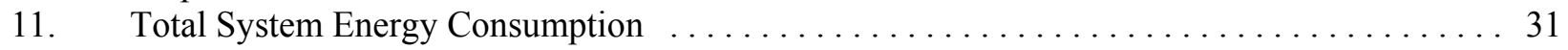

12. Nonutility qualifying Facilities Using Renewable Resources as of December 31, 1998. 


\section{Introduction}

The objective of this report is to provide an overview assessment of the state of the biopower industry and the technology for producing electricity and heat from biomass. The assessment addresses the industry status, barriers to development, feedstock characterization, lessons learned from the existing industry and selected development projects, the technical and economic characteristics of applicable technologies, the environmental performance of biopower systems, and policy issues affecting past and future development. Supporting information is supplied on the thermal and physical properties of biomass. A significant body of work exists on this subject, much of it developed through U. S. Department of Energy efforts and funding. Where applicable, existing DOE funded studies are excerpted into this report.

\section{Situation Analysis}

Biopower is a commercially proven electricity generating option in the United States, and with about $11 \mathrm{GW}$ of installed capacity is the single largest source of non-hydro renewable electricity, as shown in Figure 1. The capacity encompasses about $7.5 \mathrm{GW}$ of capacity using forest product and agricultural industry residues, about 3.0 GW of MSW-based generating capacity, and $0.5 \mathrm{GW}$ of other capacity such as landfill gas based production. The electricity production from biomass is being used and is expected to continue to be used as base load power in the existing electrical distribution system.

Figure 1: Renewable Electricity Sources

\section{Renewable Electricity Generation}

(Billion Kilowatthours)
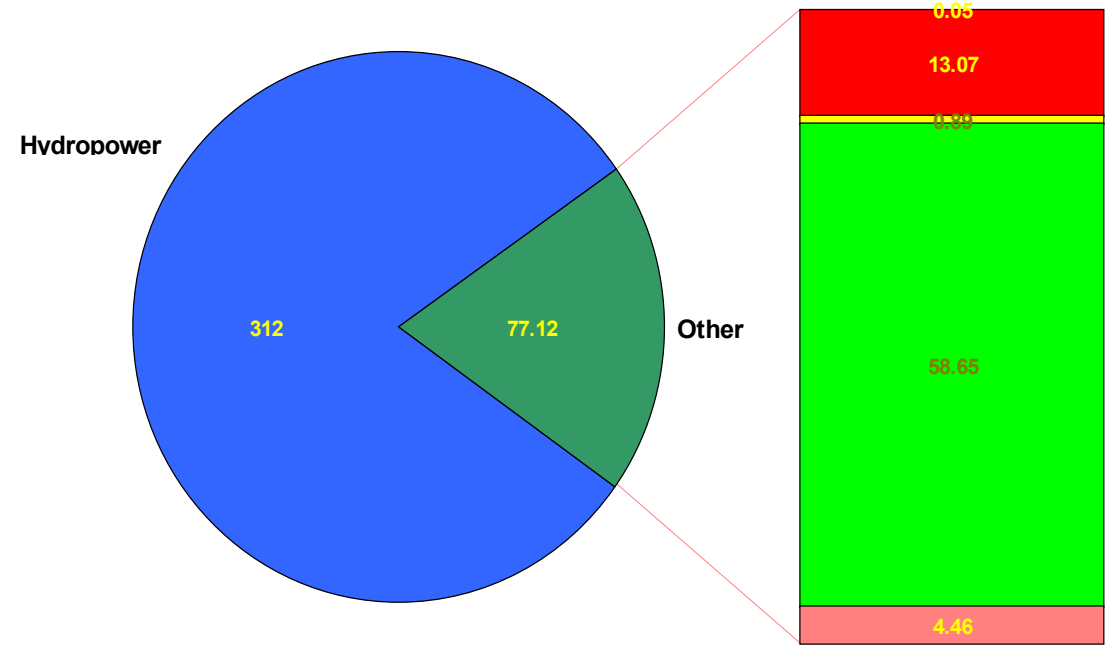

PV

Geothermal

Solar Thermal

Biomass

Wind

Source: DOE EIA Annual Energy Outlook

Biopower experienced a dramatic factor-of-three increase in grid-connected capacity after the Public Utilities Regulatory Policy Act (PURPA) of 1978 guaranteed small electricity producers (less than $80 \mathrm{MW}$ ) that utilities would purchase their surplus electricity at a price equal to the utilities' avoided cost of producing electricity. In the period 1980-1990, growth resulted in industry investment of $\$ 15$ billion dollars and the creation of 66,000 jobs. By the early 1990s the biopower industry was beginning to stall for many 
reasons - including increased feedstock costs caused by inadequate infrastructure, lack of explicit accounting for the environmental benefits in utility regulation or market costing, and much lower new-generation costs of natural gas combined cycle systems. More recently, the biopower industry has experienced uncertainty surrounding utility restructuring in a number of states. This situation has had detrimental affects on the industry that are still being felt today.

Today's capacity is based on mature, direct combustion boiler/steam turbine technology. The average size of biopower plants is $20 \mathrm{MW}$ (the largest approaches $75 \mathrm{MW}$ ) and the average efficiency is $20 \%$. The small plant sizes (which leads to higher capital cost per kilowatt-hour of power produced) and low efficiencies (which increase sensitivity to fluctuation in feedstock price) have led to electricity costs in the 8-12 $₫ / \mathrm{kWh}$ range.

The next generation of stand-alone biopower production will substantially mitigate the high costs and efficiency disadvantages of today's industry. The industry is expected to dramatically improve process efficiency through biomass cofiring in coal-fired power stations, through the introduction of high-efficiency gasification combined cycle systems, and through efficiency improvements in direct combustion systems made possible by the addition of dryers and more rigorous steam cycles at larger scale of operation. Technologies presently at the research and development stage, such integrated gasification fuel cell systems and modular systems are expected to be competitive in the future.

\section{Barriers}

There are a number of sector barriers to biopower technology development and market growth, including technology barriers and institutional—regulatory, financial, infrastructural and perceptual—barriers.

Biomass is a very desirable feedstock because it is renewable, sustainable and clean, widely available throughout the world, and amenable to conversion. However, biomass varies considerably in its elemental composition, energy content and physical characteristics. As such, it presents considerable technical challenges at virtually all phases of conversion to useful energy forms and products.

Combustion has been, for the entire history of the human species, the most common method of extracting energy from biomass (other than food) either directly, in the form of heat and light from a fire, or indirectly through use of this heat to produce steam that drives electricity-generating turbines. Direct combustion to raise steam is used in all of the existing biomass generation plants in the U.S. today. Many types of biomass used contain alkali metal species-sodium, potassium, and calcium. The combustion products of these species, chlorides, silicates, etc. can form deposits on heat transfer surfaces reducing heat transfer, and thus, overall plant efficiency. They can also accelerate the corrosion or erosion of heat transfer surfaces. Both of these mechanisms increase the maintenance requirements of the power plant. When biomass is cofired with coal (even in small percentages), these alkali species can change the properties of the resulting mixed ash, which can have a significant impact on the coal plant's operating and maintenance costs or even operability.

For cofiring to see widespread use, a number of technology-related issues must be resolved. Some, but not all cofiring tests have resulted in significant $\mathrm{NO}_{\mathrm{x}}$ reductions. The mechanisms responsible for these reductions need to be identified and taken advantage of. It must be demonstrated that a variety of biomass feedstocks - such as switchgrass, willow, and energy cane - can be effectively burned in coal boilers. This demonstration will allow these plants the fuel flexibility that the existing industry has demonstrated is necessary for economic viability. There is some concern that components of some biomass feedstocks may reduce the efficiency and effectiveness of systems for the selective catalytic reduction of $\mathrm{NO}_{\mathrm{x}}(\mathrm{SCR}$ systems). This could be a significant technical barrier to market penetration of cofiring. The existence of this problem must be confirmed or refuted and, if valid, guidelines for biomass feedstock compositions as well as possible cost-effective methods for eliminating the harmful components must be developed. 
In the longer term, gasification technologies hold the most promise for next-generation power generation efficiency improvements from combined cycles and fuel cells, as well as for production of high value coproducts along with power generation. For gasification to flourish, a number of technical barriers must be overcome. These include scale-up of the technology and replication of successful demonstrations and technologies that will aid in the integration of gasification systems with gas turbines and fuel cells. Existing technologies such as scrubbing can accomplish gas cleanup, but to achieve maximal efficiencies with minimal environmental impact, other options such as tar cracking must be developed to enhance the removal of tars and condensable organics.

A significant number of the world's two billion people who lack access to electricity have available substantial quantities of biomass resources, but lack the means to convert this resource into electricity in a clean, reliable, and efficient manner. In addition, in the developed world, distributed generation is receiving increased attention as a way of increasing energy reliability as well as the efficiency of the transmission and distribution system. To be economically competitive and environmentally acceptable, a new generation of small biopower systems is being developed. These will couple biomass conversion devices (combustors and gasifiers) to conventional and advanced electricity generators such as microturbines, Stirling engines, and eventually fuel cells. These systems must overcome a number of technical issues-including reliable and automated feeding and operation, reliable small-scale combustor and gasifier system development, and confirmation of the efficiency of small-scale gas cleaning systems and emission reduction methodologies.

All biomass energy systems have as a technical barrier the economic and energy cost of producing, transporting, and preparing the biomass feedstock. Significant progress has been made in this area, but to be truly economically competitive, new feedstocks and methods for their harvesting and preparation must be developed. Harvesting, preparation, transportation, and feeding of a variety of biomass feedstocks that are suitable for power production must be demonstrated, and new methods developed for reducing costs and energy requirements must be verified. This will reduce the delivered cost of feedstock to the energy facility to a level more competitive with fossil fuels as well as increase the return to the farmer producing the biomass.

The commercialization of renewable energy technologies can be impeded by barriers that do not involve technical issues. Technological progress that improves performance or increases system efficiency can open doors to deployment; however, market growth ultimately depends on overcoming the institutional challenges. The keys to the successful implementation of energy technologies, and in particular, biopower technologies, are overcoming issues that can be categorized as the following - regulatory, financial, infrastructural, and perceptual.

Through the regulatory process, governments direct activities in the broader societal interest. Regulations usually pertain to two broad issues: (1) markets and (2) health, safety, and environmental protection. Regulatory factors can create technology development opportunities and barriers that would not exist in unregulated environments. The restructuring of the power industry is providing new opportunities for biopower. Markets are developing for "green power," where electricity from selected generation sources can be sold at high prices - typically 1-2 cents per kilowatt-hour above market. Increased biopower generation is being encouraged through Renewable Portfolio Standards (RPS).

In the United States, the regulations that control the release of oxides of sulfur $\left(\mathrm{SO}_{2}\right)$ and nitrogen $\left(\mathrm{NO}_{\mathrm{x}}\right)$ are rapidly tightening under a variety of cap and trading schemes now being proposed for pollutants, particularly for $\mathrm{NO}_{\mathrm{x}}$. These regulations may work as a potential boon to biopower because technologies such as cofiring improve utilities' emissions profiles in $\mathrm{SO}_{\mathrm{x}}$ and $\mathrm{NO}_{\mathrm{x}}$. However, in some instances, EPA regulations and policies discourage existing coal plants from cofiring by opening them up to New Source Reviews if they modify their existing plants to accept biomass. In the future, the potential regulation of greenhouse gas emissions will likely result in a particular advantage for the carbon dioxide neutral biopower technology. 
Financial constraints pertain to the availability and cost of a project and to the overall financial attractiveness of renewable energy technologies. Capital markets generally perceive the deployment of emerging technologies as involving more risk than established technologies. The higher the risk, the higher the rate of return demanded on capital thus impacting the rate of investment in these new, emerging technologies. Tax incentives for renewable energy technologies have been enacted by Congress to encourage commercialization. Under the Energy Policy Act of 1992 (EPACT), electricity production from wind and biomass grown from energy crops became eligible for a $1.5 \phi / \mathrm{kWh}$ production incentive, available for 10 years. This production incentive is restrictive as the provisions only allow for "closed loop biomass" (crops grown exclusively for power generation). To date, in the biomass area, ethanol is the main beneficiary of tax policy.

Infrastructure is a general term for the entire energy service production and delivery system. It involves decisions made by a broad range of players including consumers, energy service providers like utilities, fuel suppliers, and others. The nature of biomass technology requires infrastructure development for the supply of feedstocks and distribution of products. Unlike fossil fuels such as coal and natural gas, which have a highly developed and sophisticated infrastructure in the U.S. via railroad transportation and pipelines, a similar infrastructure does not currently exist for biomass. Presently, biomass supplies are dominated by lowcost residues streams consisting of materials generated by industries that process biomass for fiber or food uses-paper mills, lumber mills, sugar mills, etc.-or other economic activities-agriculture, urban construction and demolition, waste generation, etc. The quality, quantity, and cost of these resources continually vary in response to economic growth rates, discount factors, and regulation, e.g., the regulation of landfill activity and policies towards recycling.

In the future, a dedicated feedstock supply system based on short-rotation woody crops and herbaceous perennial crops could dramatically expand the assured availability of biomass for energy applications. Establishing a Biomass Reserve Program (BRP) of perennial tree and grass crops that are particularly suitable for low-quality cropland like that currently enrolled in the Conservation Reserve Program (CRP) could help to remove some infrastructural barriers related to the cost and supply of feedstocks. Another problem associated with the technology infrastructure concerns the 50-mile supply radius for the economic collection and transportation of fuel.

Many people still do not know what the term "biomass" means, let alone understand some of the benefits and new technology developments associated with biomass. In addition, some environmental groups do not view biomass as a "green" technology. Awareness of biomass tends to be associated with wood stoves and concerns over emissions with the combustion of wood than with biomass as an alternative energy technology. Less is known by the public and others about the low emissions, high efficiency, and environmental benefits offered with state-of-the-art biomass power systems. There are also concerns related to harvesting of trees as well as the need for sustainable supply. These unfavorable perceptions translate into financial costs and risks to any biomass project. Only with considerable education efforts and demonstration that environmental concerns are being accounted for can the risks of nonacceptance be overcome.

\section{Feedstock Supply}

Biomass resources are generally classified into five major categories - urban wood waste, mill residues, forest residues, agricultural residues, and dedicated energy crops. The availability, characteristics, and acquisition costs of each of these resources are very different. Availability and price estimates for urban wood wastes and forest residues are highly uncertain and depend on local conditions. Availability of mill residues and agricultural residues can be estimated more precisely; however, prices depend on local market conditions and, in the case of agricultural residues, cropping patterns and environmental restrictions. Energy crops are not currently grown as fuel feedstock and availability and prices are therefore more speculative. 
It is estimated that about 24 million dry tons of biomass might be available nationally to conversion facilities at delivered prices of about $\$ 25 /$ dry ton or less $(\$ 1.60 / \mathrm{MMBtu})$. The amount of biomass available increases more than fourfold at prices under $\$ 35 /$ dry ton ( $\$ 2.20 / \mathrm{MMBtu})$. At prices under $\$ 55 /$ dry ton $(\$ 3.40 / \mathrm{MMBtu})$, over 510 million dry tons are potentially available annually. State level estimates are provided in Table 1. No assumptions about the spatial distribution of feedstock within states are made, and proposed conversion facilities may not be within an economically feasible transport area. Feasibility studies of proposed conversion facilities must include detailed local analyses to verify feedstock availability, prices, and reliability.

\section{Lessons Learned-California Biopower Industry}

California has one of the largest and most diverse biomass energy industries in the world. At its peak, the California biomass energy industry produced almost 4.5 billion $\mathrm{kWh}$ per year of electricity, and provided a beneficial use outlet for more than 10 million tons per year of the state's solid wastes. The peak, however, occurred during the early 1990s. Since that time a quarter of the biomass energy facilities have agreed to buyouts of their power sales contracts and terminated operations, while others have reduced their operations. This has occurred because of concerns about the long-term viability of these facilities in a competitive, deregulated electricity market.

California has a diversity and extent of agriculture and forestry industries unrivaled in the world. Both activities produce large quantities of solid wastes, many of which are biomass residues that can be used as fuel. Before the federal Public Utilities Regulatory Policy Act (PURPA) was passed in 1978, only a few biomass-fired boilers were operating in California, and little electricity was being generated from biomass. During a period of less than 15 years (roughly 1980-1993), nearly 1,000 MW of biomass generating capacity were placed into service. The biomass energy sector expanded from an outlet for a small quantity of the state's wood processing residues to an essential component of the state's solid-waste disposal infrastructure. Today the California biomass energy industry provides a beneficial use for almost 6.5 million tons of the state's solid wastes. Figure 2 graphically illustrates the development of the biomass energy generating industry in California from 1980 to the present.

During the late 1980s the attention of the biomass generating facilities focused on a potential crisis in the biomass fuels market. As the state's installed biomass generating capacity grew rapidly during the later half of the 1980s, the demand for fuel soon overwhelmed the readily available supply. Virtually all sawmill and food processing residues that did not have higher valued uses were being sold into the fuel market, and still there was a significant deficit between biomass supply and demand. Numerous efforts were under way to develop technologies to produce biomass fuels from new sources of supply, such as agricultural prunings, agricultural field residues, forestry residues, and urban waste wood, with rising fuel prices providing the incentive. The state's biomass fuels crisis peaked in 1990 with average prices topping $\$ 40 / \mathrm{bdt}$ of fuel, and spot prices reaching $\$ 60 /$ bdt or higher. Moreover, several major new facilities were approaching the completion of construction, and there was a fear that biomass fuel prices might continue to rise. The early years of the 1990s saw the state's biomass energy industry stabilize at a level of about 750 MW of operating capacity. The California biomass fuels market also stabilized during the early 1990s, with average market prices settling at a level of about $\$ 37.50 / \mathrm{bdt}$, at an average consumption level of approximately 9 million tons per year. The historical California biomass fuel market is shown in Figure 3. Figure 4 shows a plot of the supply curve for biomass fuels in California. The data points represent the period 1986 to the present, showing, for each year in the range, the quantity of biomass fuel used and the average price. 
Table 1: Estimated Biomass Resources Available by State and Price

\begin{tabular}{|c|c|c|c|c|}
\hline \multirow[t]{3}{*}{ State } & \multicolumn{4}{|c|}{ Delivered price ( $\$ /$ dry ton) } \\
\hline & $<25$ & $<35$ & $<45$ & $<55$ \\
\hline & \multicolumn{4}{|c|}{ thousand dry tons } \\
\hline Alabama & 841 & 6,963 & 10,712 & 17,682 \\
\hline Arizona & 220 & 575 & 863 & 1,100 \\
\hline Arkansas & 402 & 4,092 & 7,086 & 13,604 \\
\hline California & 1,588 & 6,158 & 8,224 & 11,299 \\
\hline Colorado & 181 & 652 & 3,357 & 3,582 \\
\hline Connecticut & 247 & 561 & 611 & 906 \\
\hline Delaware & 39 & 95 & 194 & 462 \\
\hline Florida & 2,762 & 6,524 & 6,778 & 9,533 \\
\hline Georgia & 934 & 6,391 & 8,541 & 16,112 \\
\hline Idaho & 204 & 2,572 & 4,117 & 7,166 \\
\hline Illinois & 435 & 1,038 & 26,839 & 33,359 \\
\hline Indiana & 348 & 994 & 13,410 & 18,607 \\
\hline Iowa & 174 & 404 & 24,583 & 32,786 \\
\hline Kansas & 737 & 1,283 & 12,733 & 21,344 \\
\hline Kentucky & 455 & 1,472 & 5,758 & 10,809 \\
\hline Louisiana & 516 & 3,569 & 7,977 & 11,834 \\
\hline Maine & 151 & 1,196 & 1,572 & 2,214 \\
\hline Maryland & 205 & 543 & 900 & 1,959 \\
\hline Massachusetts & 419 & 939 & 1,027 & 1,436 \\
\hline Michigan & 506 & 2,468 & 4,627 & 12,163 \\
\hline Minnesota & 991 & 2,917 & 15,494 & 21,247 \\
\hline Mississippi & 599 & 4,909 & 10,673 & 17,931 \\
\hline Missouri & 478 & 1,346 & 8,030 & 19,523 \\
\hline Montana & 69 & 1,422 & 2,159 & 6,761 \\
\hline Nebraska & 114 & 210 & 18,467 & 21,773 \\
\hline Nevada & 184 & 315 & 333 & 337 \\
\hline New Hampshire & 134 & 922 & 1,061 & 2,016 \\
\hline New Jersey & 389 & 726 & 791 & 976 \\
\hline New Mexico & 168 & 424 & 961 & 1,082 \\
\hline New York & 1,168 & 3,328 & 3,885 & 8,438 \\
\hline North Carolina & 669 & 4,188 & 5,790 & 10,856 \\
\hline North Dakota & 327 & 558 & 2,507 & 21,043 \\
\hline Ohio & 745 & 1,473 & 13,018 & 18,963 \\
\hline Oklahoma & 111 & 3,874 & 7,816 & 12,700 \\
\hline Oregon & 193 & 3,341 & 4,126 & 9,810 \\
\hline Pennsylvania & 572 & 2,206 & 2,832 & 7,427 \\
\hline Rhode Island & 30 & 81 & 88 & 116 \\
\hline South Carolina & 1,294 & 4,469 & 6,332 & 9,368 \\
\hline South Dakota & 132 & 286 & 9,602 & 16,005 \\
\hline Tennessee & 878 & 3,382 & 10,720 & 15,233 \\
\hline Texas & 1,227 & 4,222 & 13,526 & 20,747 \\
\hline Utah & 159 & 388 & 648 & 723 \\
\hline Vermont & 41 & 392 & 513 & 1,023 \\
\hline Virginia & 599 & 3,059 & 5,055 & 8,715 \\
\hline Washington & 297 & 3,979 & 5,939 & 9,920 \\
\hline West Virginia & 241 & 1,361 & 1,972 & 3,736 \\
\hline Wisconsin & 425 & 2,450 & 11,502 & 14,963 \\
\hline Wyoming & 224 & 552 & 787 & 1,466 \\
\hline Total & 23,820 & 105,267 & 314,535 & 510,855 \\
\hline
\end{tabular}



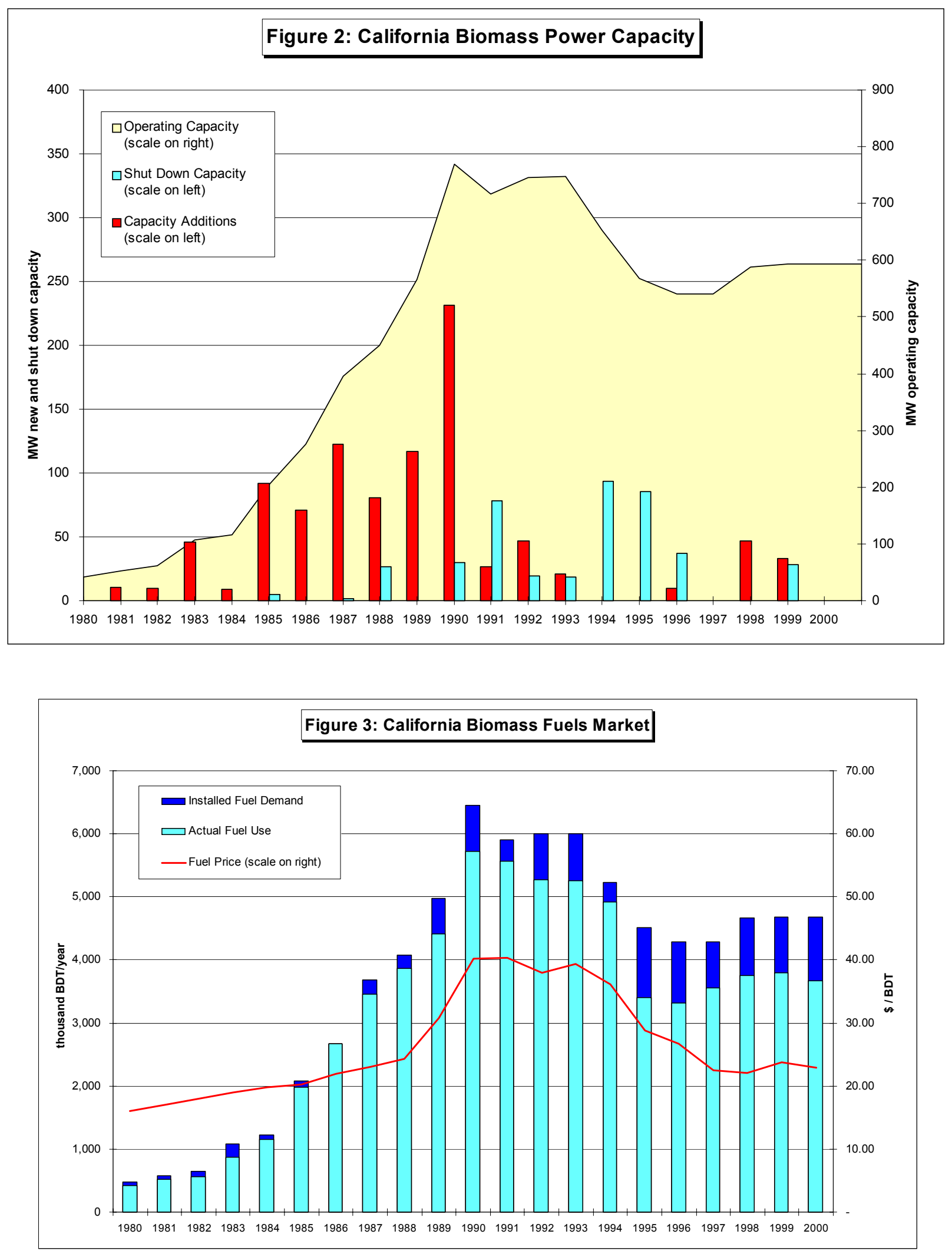
The stability, however, was short lived. In April 1994 the California Pubic Utilities Commission (CPUC) issued its landmark Blue Book proposal for restructuring the state's regulated electric utility industry (CPUC 1994). The Blue Book proposal provided for competition among generating sources on the basis of price alone, without regard to non-market factors such as resource diversity and environmental impact. This represented a major threat to biomass energy generation. Because of the low density of biomass fuels and the resultant high handling and transportation costs, the relatively small size of biomass generating facilities, and the low cost of natural gas, the cost of power production from biomass was inherently higher than the cost of power generation using natural gas. The most immediate effect of the Blue Book restructuring proposal for the biomass energy industry was that it provided an incentive for the state's regulated electric utility companies to buy out the Standard Offer No. 4 power purchase agreements (SO\#4 PPAs) held by the biomass generators in their service territories. Many biomass generators were receptive to these offers because of their concern about their own long-term liabilities to the utility companies in connection with the firm-capacity obligations in their contracts. Over the next 3 years, 17 biomass facilities, rated collectively at more than 215 MW, accepted buyout offers and shut down operations. Annual biomass fuel use in the state shrank by $37 \%$ during the 2 years following the appearance of the Blue Book proposal.

Despite the uncertainty over the future viability of biomass energy production in California, the state's biomass energy industry operated with relatively stability during the latter half of the 1990s. Following the shutdowns of 1994-1996, 27 biomass facilities, representing 540 MW of generating capacity, remained in operation. Twenty operated under intact SO\#4s. The other seven had special circumstances, such as a captive fuel supply or an ability to earn retail-offset for most or all of their electricity output, that allowed them to continue operating. The fixed-price periods in the SO\#4 PPAs came to an end at the end of the 1990s, but the renewables transition fund created by $\mathrm{AB} 1890$ offered biomass generators a supplement of $1.5 \mathrm{c} / \mathrm{kWh}$ for facilities that did not receive SO\#4 fixed-scheduled prices for their sales of electricity.

The operating biomass energy generating capacity in California actually increased slightly at the end of the 1990 s, to almost $600 \mathrm{MW}$. This was mainly because two 25-MW facilities that had accepted contract buyouts and shut down operations in 1994 had special provisions in their buyouts that provided for restarting the facilities at the end of their fixed-price periods. These facilities resumed operations in 1998 and 1999, respectively. Biomass fuel use increased by $15 \%$ over its low point following the 1994-1996 shutdowns.

In 2002, California had thirty-five biomass power plants in operation, representing a total of $685 \mathrm{MW}$ of electricity generating capacity. Approximately two-thirds of the total were operating under old standard-offer power purchase agreements with fixed energy prices that will remain in effect through the middle of 2006. These facilities are well served by their contracts, and should be able to operate viably until at least that time. The other one-third of California's biomass power plants are operating under interim 90-day contracts that provide them with minimally acceptable operating revenues. The long-term fate of this group of facilities is a function of whether they are ultimately able to obtain longer-term contracts with adequate power purchase provisions.

Although the California electric power market has been very volatile, some fundamental lessons can be learned in a review of biopower in the State. Because of the small size of biopower facilities-governed by PURPA size limitations and cost of fuel transportation-and the high price of fuel compared to traditional fossil fuels, costs of electricity are higher than competing sources of electricity. To enable market penetration, government support in the form of incentives or regulation is needed. PURPA enabled growth of the California biopower industry. However, with the lapsing of PURPA and changes in the California electric structure to a competitive, lowest cost provider model, the industry began a period of stagnation and decline. Although it is common sense, this supports traditional economics. Absent government support, commodity providers with above market costs cannot successfully compete in a free market. In such cases government support is required to maintain viability. Within the biopower industry, low cost providers have the most stability. 


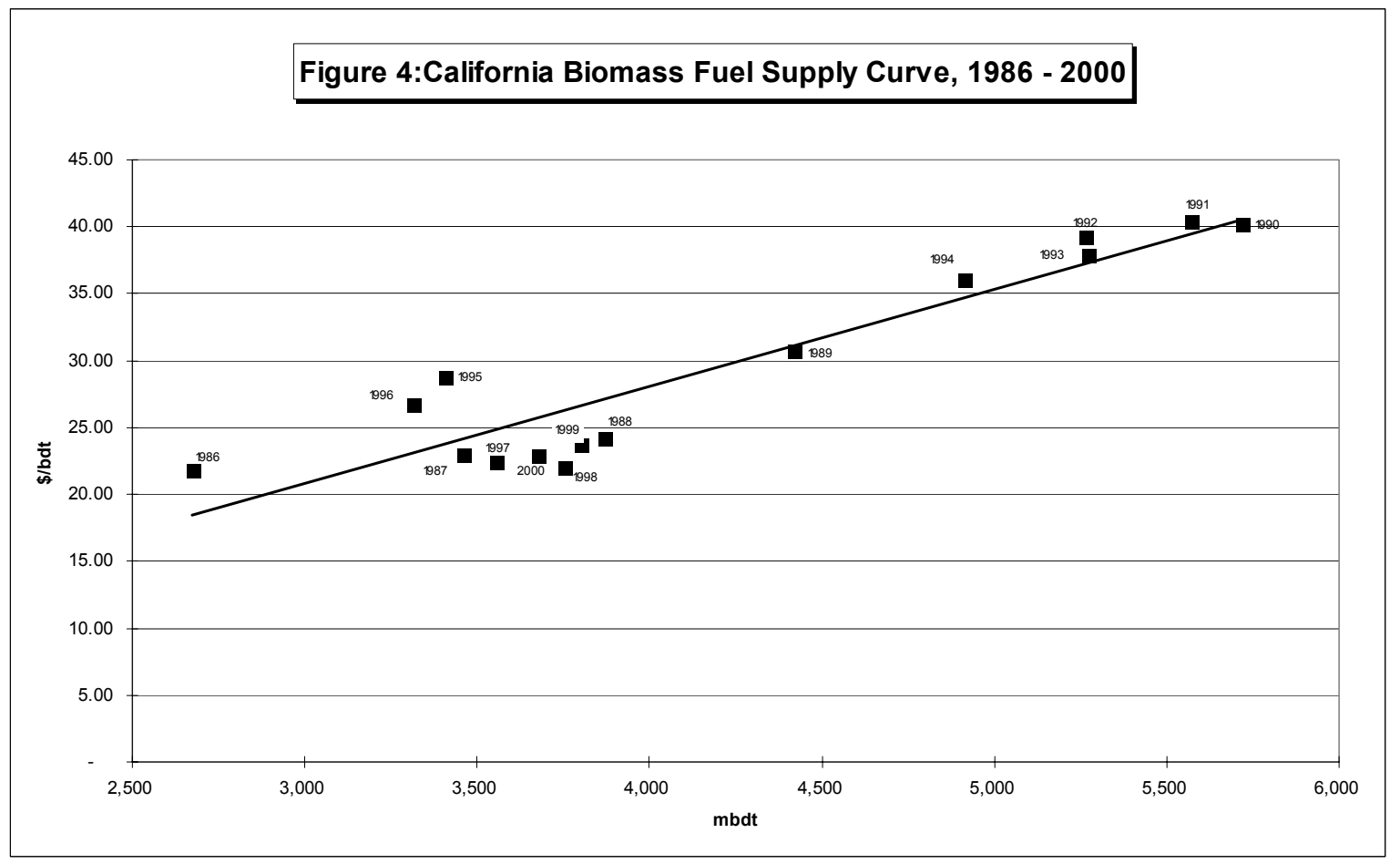

The biomass fuels market in California represents a very diverse set of fuels-agricultural residues, forestry residues, and urban wood residues. A review of historical fuel prices shows that fuel prices have classical supply and demand characteristics, with market price driven by the marginal costs of the most expensive feed.

\section{Lessons Learned-Existing Industry}

Summary survey information is presented on 20 biomass power plants - 18 in the United States, one in Canada, and one in Finland - that represent some of the leaders in the industry. The on-line dates of the plants span about 18 years, from December 1979 to January 1998. Many boiler types are represented: six traveling grate stoker boilers, four water-cooled vibrating grate boilers, four bubbling fluidized bed combustors (FBCs), one circulating fluidized bed (CFB) boiler, one fixed-grate boiler, one sloping grate boiler, and two pulverized coal (PC) boilers retrofitted to cofire solid or gasified biomass. Steam temperatures for the biomass-fired boilers are $750^{\circ}-980^{\circ} \mathrm{F}$; for the $\mathrm{PC}$ boilers, $1004^{\circ}-1005^{\circ} \mathrm{F}$. The nominal sizes of the plants range from $10 \mathrm{MW}$ to $79.5 \mathrm{MW}$.

Lessons learned are summarized below:

Fuel: The highest priority at most biomass power plants is to obtain the lowest-cost fuels possible. This involves tradeoffs in fuel quality, affects the design and operation of the system, and frequently is limited by permit requirements.

Fuel Yard and Fuel Feed System: The area of a biomass power plant that can almost be counted on to be mentioned in response to the question "Have you had any significant problems or lessons learned?" is the fuel yard and fuel feed system. Most plants spent significant time and money during the first year or two of operation, solving problems such as fuel pile odors and heating, excessive equipment wear, fuel hangups and bottlenecks in the feed system, tramp metal separation problems, wide fluctuations in fuel moisture to the boiler, etc., or making changes in the fuel yard to respond to market opportunities. 
Table 2: Biomass Plants Surveyed

\begin{tabular}{|c|c|c|c|c|c|c|c|}
\hline Plant & Online & Fuels & Boiler(s) & $\mathbf{l b} / \mathbf{h r}$ & $\underline{\text { Psig }}$ & $\mathbf{D F}$ & MWe \\
\hline Bay Front & Dec-79 & Mill, TDF, coal & 2 modified coal stokers & 280,000 & & & 30 \\
\hline Kettle Falls & Dec-83 & Mill & 1 traveling grate stoker & 415,000 & 1500 & 950 & 46 \\
\hline McNeil & Jun-84 & Forest, mill, urban & 1 traveling grate stoker & 480,000 & 1275 & 950 & 50 \\
\hline Shasta & Dec-87 & Mill, forest, ag, & 3 traveling grate stokers & 510,000 & 900 & 905 & 49.9 \\
\hline El Nido (closed) & Oct- 88 & $\mathrm{Ag}$, forest, mill, & 1 bubbling FBC & 130,000 & 650 & 750 & 10 \\
\hline Madera (closed) & Jul-89 & $\mathrm{Ag}$, forest, mill, & 1 bubbling FBC & 260,000 & 850 & 850 & 25 \\
\hline Stratton & Nov-89 & Mill, forest & 1 traveling grate stoker & 400,000 & 1485 & 955 & 45 \\
\hline Chowchilla II (closed) & Feb-90 & $\mathrm{Ag}$, forest, mill, & 1 bubbling FBC & 130,000 & 650 & 750 & 10 \\
\hline Tracy & Dec-90 & $\mathrm{Ag}$, urban & 1 water-cooled vib grate & & & & 18.5 \\
\hline Tacoma (cofiring) & Aug-91 & Wood, RDF, coal & 2 bubbling FBCs & & 400 & 750 & 12 \\
\hline Colmac & Feb-92 & Urban, ag, coke & 2 CFB boilers & 464,000 & 1255 & 925 & 49 \\
\hline Grayling & Aug-92 & Mill, forest & 1 traveling grate stoker & 330,000 & 1280 & 950 & 36.17 \\
\hline Williams Lake & Apr-93 & Mill & 1 water-cooled vib grate & 561,750 & 1575 & 950 & 60 \\
\hline Multitrade & Jun-94 & Mill & 3 fixed grate stokers & 726,000 & 1500 & 950 & 79.5 \\
\hline Ridge & Aug-94 & Urban, tires, LFG & 1 traveling grate stoker & 345,000 & 1500 & 980 & 40 \\
\hline Greenidge (cofiring) & Oct-94 & Manufacturing & 1 tangentially-fired PC & 665,000 & 1465 & 1005 & $10.8^{*}$ \\
\hline Camas (cogen) & Dec-95 & Mill & 1 water-cooled vib grate & 220,000 & 600 & 750 & $38-48$ \\
\hline Snohomish (cogen) & Aug-96 & Mill, urban & 1 sloping grate & 435,000 & 825 & 850 & 43 \\
\hline Okeelanta (cogen) & Jan-97 & Bagasse, urban, & 3 water-cooled vib grate & $1,320,000$ & 1525 & 955 & 74 \\
\hline Lahti (cofiring, cogen) & Jan-98 & Urban, RDF & 1 CFB gasifier + PC & 992,000 & 2500 & 1004 & $25 * *$ \\
\hline
\end{tabular}

Design for Fuel Flexibility: Many biomass plants change fuels significantly over the years, as opportunities arise or old fuel sources dry up. These changes are often not predictable. The best strategy to deal with this problem is to have a plant design and permits that allow as much fuel flexibility as possible.

Location: As realtors say, "Location, location, location!" Biomass residues and wastes are local fuels, with very low energy densities compared to fossil fuels. Transport costs become very significant after about 20 miles, and usually prohibitive beyond 100 or 200 miles. The ability to have the waste generators deliver the fuel to the plant site at their own expense requires a location very close to the sources of waste. There are also other considerations, such as the proximity to residential neighborhoods.

Reliability and Dependability: Several plant managers with the best long-term operating records stressed the necessity for placing a high value on reliability and dependability. This is true during plant design and equipment selection, and during operation.

Partnerships: The most successful projects have developed formal or informal partnerships with their key customers and suppliers. The relationship with the utility company that buys the power is usually the most important. This may change as generators simply bid their power into a power pool. Cogeneration plants by definition must have close relationships with their steam users. Sometimes there are a few large fuel suppliers (such as sawmills) with whom special relationships are crucial.

Cofiring: Once the availability of low-cost biomass fuel is established, the primary issue addressed in most retrofitted cofiring projects is how to feed the fuel (and in what form to feed it) to the coal-fired boiler. There are of course many other issues, such as effects on boiler operations, plant capacity, emissions, and ash quality. 
Benefits: The 20 biomass projects provide many concrete illustrations of environmental and economic benefits. The Kettle Falls, Williams Lake, and Multitrade plants provide air quality benefits in rural settings where sawmills used to pollute the air with teepee burners. The Ridge, Tacoma, and Lahti plants serve urban areas by burning urban waste fuels cleanly; Lahti provides district heat as well. The Okeelanta, Tracy, and San Joaquin plants burn agricultural residues cleanly, which formerly were burned with no emission controls. The Shasta, McNeil, and Grayling plants serve the forest management operations in their areas by cleanly burning non-merchantable wood, brush, and limbs.

\section{Lessons Learned-Demonstration Projects}

A brief discussion of the lessons learned from two DOE gasification demonstration projects is given.

\section{Hawaii Project}

The Hawaii biomass gasification project was a multi-phase gasifier demonstration jointly supported by the Department of Energy, the State of Hawaii, and Hawaii Commercial and Sugar Company (HC\&S) at the HC\&S Paia, Maui, Hawaii sugar mill between 1991 and 1997. The project was originally conceived to produce a synthesis gas for methanol production from bagasse, the solid residue from sugar cane processing. The application was converted to producer gas production for electricity generation because of a DOE reorganization that moved management of gasification projects to the Biopower Program. The project involved scale-up of the Institute of Gas Technology RENUGAS ${ }^{\text {TM }}$ high-pressure, bubbling-fluid-bed, airblown gasifier to the 100 ton-per-day scale. The project was divided into two phases. The first, managed by the Pacific International Center for High Technology Research tested a plug screw feeder design. The second, managed by Westinghouse Electric Corporation, tested a more conventional lock hopper feeder system. Operation of the system was difficult, with feed system problems encountered for the duration of the project. The project was closed in 1997 when the funding partners determined that the project could not be converted to a commercial project.

A brief summary of lessons learned for the Hawaii project is given below.

\section{Non-technical}

- Impact of Initial Cost Increase: Major experimental programs of this nature must have the leadership of a commercial $\mathrm{E} \& \mathrm{C}$ firm during the design and construction phase.

- Environmental Assessment: The most important lesson coming out of the environmental permitting process is that solicitations should require substantial environmental reviews before committing to the decision to proceed with a project. Given the time and expense to perform such reviews, the time and cost impacts of environmental assessments should be included in project plans. To a large extent the Biomass Power Program has learned from the Hawaii Project in this area. The Vermont Project was able to structure a project involving feeding the product gas to an existing boiler, without requiring a complete evaluation of the existing power plant permits, and using the using the existing boiler emission permits.

- Impact of the Energy Policy Act of 1992: DOE was required to evaluate the project under the rules of EPAct92. Given the requirement by the State of Hawaii for commercial application for funding, a DOE determination was made that the project was a commercial, not experimental, project. The conversion into a commercial project placed expectations on the project that could not be met. Commercialization required a number of conditions to be met. HS\&S, the host company, needed to agree to assume ownership of the facility. They did not. Since the completion of the Hawaii project, HC\&S has closed the Paia mill. Second, the facility was an experimental unit at a small scale. The capital cost of an experimental facility and the associated labor-intensive design (needed for experimental data gathering/analysis but not commercial operation) made the commercial cost of electricity 
uneconomic. Although the stated experimental goals were not reached in the proposed time, much valuable technical experience was gained in material handling systems, and in system integration. Therefore, the project was successful in addressing issues in start-up, testing and evaluation of scaling up biomass gasification technology.

- TVP Project: The advisory groups should not have been disbanded. On highly developmental projects of this nature, limiting technical input greatly increases technical risk.

\section{Technical}

- Impact of Initial Cost Increase: Bagasse is an extremely difficult feedstock. Organizations with direct operating and design experience should be involved in bagasse projects. Decisions to modify the feed system design to fit within the allowable funding did not recognize the potential for technical difficulties and led to the majority of operational difficulties through the life of the project.

- Phase 1 Equipment Decisions: Uniformity of feed is critical to the successful operation of a gasifier. The use of a feeder designed for a particular feed, rather than adaptation of a system not designed as a process feed system is needed.

- $\quad$ Phase 1 Equipment Decisions: We need to do a better job of evaluating the ability of the non-Federal partner to operate new equipment such as the plug-screw feeder. We probably would have had more success using a system closer to commercialization.

- $\quad$ Phase 1 Equipment Decisions: We should more carefully evaluate the details of equipment. In the case of the plug-screw feeder, the use of a lubrication system would have eliminated many of the problems with overheating and high-current draws.

\section{Minnesota Alfalfa Producers (MNVAP) Project}

MnVAP was incorporated as a cooperative under chapter 308A of the laws of the State of Minnesota in December 1994. MnVAP is an agricultural cooperative, currently owned by nearly 500 alfalfa farmers in western Minnesota. The company was formed in response to the interest shown by DOE, USDA, and others, in the development of biomass electric projects that use farm-grown, closed loop energy crops as primary fuels. In early 1995, NSP requested proposals to supply biomass generation resources to satisfy the first phase of the Biomass Mandate. MnVAP and its project team submitted two proposals to NSP: one for a biomass gasification combined-cycle power plant, and another for a conventional power generation plant. Each project would use alfalfa sterns as a prirnary fuel source. The original design of the project called for a Tampella Power gasification island and a 75-megawatt combined-cycle power plant with a Westinghouse 251B combustion turbine. At full production, the power plant would require nearly 350,000 tons of alfalfa stem material per year.

In late 1996, NSP selected MnVAP's biomass gasification combined-cycle project for negotiation of a PPA. MnVAP and NSP executed an MOU that outlined the terms to be incorporated in a power purchase agreement. By the end of 1997, MnVAP executed a long-term PPA with NSP. It was expected that this would provide long-term project viability. Execution of the PPA justified accelerated development work to prepare for financial closing and start of construction.

Phase I of the cooperative agreement provided DOE funds on a cost-shared basis to complete work in seven major project task areas. Each task area supported completion of items necessary for the MAP Project to reach financial closing and start construction; however, there was insufficient time to begin commercial operations before the end of the calendar year 2001, the date by which NSP was required to bring biomass resources on line. Most tasks were completed, or were progressing well, but development work was suspended prior to financial closing de to a combination of events precipitated largely by regulatory delays. 


\section{$\underline{\text { Summary of Lessons Learned: Minnesota Agri-Power Project }}$}

- Vendor Guarantees and Warranties: If plant configuration has not been tested, and/or if the feed has not been tested, then extended pilot testing is required ( 1000 - 2000 hours at steady state conditions) to develop vendor confidence leading to guarantees and warranties for commercial operation.

- $\quad$ Pilot Plant Experience: Such testing may be doubly important when guarantees and warranties are needed from "downstream" unit operation vendors such as gas clean-up, gas turbine and stearn turbine original equipment manufacturers.

- $\quad$ Project Scale-Up: A scale-up of ten times is too large to incorporate guarantees and warranties for untested processing steps or combinations of unit operations.

- Project Financing: Developmental projects are inherently risky. Need to develop creative approaches to investment and financing arrangements.

- $\quad$ Entering New Markets: Must develop a marketing plan and study existing markets for agriculturally-based and other potential feedstock products. Expect resistance (political and economic) from current market suppliers.

- Feedstock Suitability and Flexibility: Need to develop criteria for suitability offeedstocks for electrical conversion. If possible, design conversion system to be capable of handling multiple feedstocks.

- Technical Readiness: DOE needs to perform in-depth reviews of the technical status of development in relation to the proposed commercial project to better estimate the technical/commercial feasibility of the project. At a minimum the project technical development time and cost should be reviewed in detail.

- Reviews Prior to Award: A detailed technical review is required at the solicitation technical review stage to identify technology readiness for commercialization, rather than addressing such issues after agreements have been reached and project timing and costs contractually set.

\section{Key Success Factors}

Successful commercial implementation of technology is dependent on a wide range of positive and negative drivers. A preliminary analysis was performed that identified drivers in the areas of policy, corporate policy, regulation, legal, infrastructure, and technology, and used to develop a preliminary methodology for ranking relative importance. The analysis methodology involves development of an estimate of the impact of drivers on CHP systems (high, medium, low), the relative importance of each driver, and the probability of the driver occurring by 2020 . Multiplying the three factors gives a weighted probability of the impact. This weighted probability can be normalized to $100 \%$ and ordered in terms of numerical importance. An example of the rating of drivers was estimated by the authors to demonstrate the methodology. Eventually, it would be desirable to ask a group of experts in the area to provide independent estimates of factors, and then develop a group evaluation of drivers. Table 3 presents a summary of key drivers, ranked by weighted probability. 
Seventy-five percent of the positive drivers are given by 10 factors in the categories of technology, corporate policy, regulation, and finance. The top three positive factors are the technology maturity of combustion and cofiring systems, the corporate need for CHP, and Federal mandates such as PURPA. Seventy-five percent of the negative drivers are given by nine factors in the categories of finance, corporate policy, and legal. The top three negative factors are lack of feedstock infrastructure, the cost of products compared to traditional sources, a corporate resistance to new technology introduction.

A qualitative comparison of key success factors relative to coal and natural gas was made and is presented in Table 4. In general, biomass systems compare favorably with new coal facilities, especially in the area of environmental impact. In general, biomass systems do not compare favorably with natural gas systems, except in the area of environmental impact. 
Table 3: Key Drivers for Biomass CHP Systems

Category KEY DRIVERS
Weighted Weighted

Probability Cumulative

$\%$ of Total Probability

$\%$ of Total

Ref

\section{POSITIVE FACTORS}

\begin{tabular}{cl} 
W & Technology \\
N & Corp Policy \\
E & Regulation \\
O & Finance \\
U & Finance \\
B & Regulation \\
D & Finance \\
M & Corp Policy \\
J & Finance \\
R & Finance \\
\hline C & Policy \\
G & Regulation...... \\
H & Regulation \\
K & Finance \\
P & Technology \\
V & Finance \\
A & Policy \\
X & Legal \\
F & Infrastructure \\
L & Corp Policy \\
S & Corp Policy \\
I & Policy \\
T & Finance \\
&
\end{tabular}

Technology Maturity, Combustion and Cofiring Corporate Use/Need for CHP

$13.5 \%$

$10.8 \%$

$24.3 \%$

Federal Mandates, e.g., PURPA, RPS

$9.0 \%$

Use of Existing Residues

Cofiring Capital Cost

$9.0 \% \quad 42.2 \%$

Air Emissions Controls

$8.1 \%$

$6.7 \%$

$4.5 \%$

Federal Tax Incentives for RE

Corporate RE Mandate

$4.5 \%$

Fuel Price Volatility (coal, oil, natural gas) $\quad 4.0 \%$

Cost of Fuel - Stability

State Programs for RE

$4.0 \%$

Distributed Energy Certification Standards

$3.4 \%$

Electricity Wheeling

$2.7 \%$

Fuel Supply Disruptions (Oil, Natural Gas)

$2.7 \%$

$2.7 \%$

Alternative Future Uses, e.g., SYNGAS

$2.7 \%$

Production of Export Electricity

$2.7 \%$

National Security (Domestic Sourcing Rulings)

$2.2 \%$

Environmental Community Acceptance $2.2 \%$

Transmission Bottlenecks / Disruptions

$1.3 \%$

Corporate Energy Autonomy

Support of Local Economy - Indigenous Feed

$1.3 \%$

Climate Change Policy (international)

$0.9 \%$

Low Interest Rates

$0.4 \%$

$0.4 \%$

$13.5 \%$

$33.3 \%$

$42.2 \%$

$57.1 \%$

$61.6 \%$

$66.1 \%$

$70.1 \%$

$74.2 \%$

$77.5 \%$

$80.2 \%$

$82.9 \%$

$85.6 \%$

$88.3 \%$

$91.0 \%$

$93.3 \%$

$95.5 \%$

$96.9 \%$

$98.2 \%$

$99.1 \%$

$99.6 \%$

$100.0 \%$

\section{NEGATIVE FACTORS}

\begin{tabular}{|c|c|c|c|c|}
\hline CC & Finance & Feedstock Infrastructure & $11.3 \%$ & $11.3 \%$ \\
\hline JJ & Finance & Cost of Products & $10.8 \%$ & $22.1 \%$ \\
\hline AA & Corp Policy & Resistance to Change & $9.1 \%$ & $31.2 \%$ \\
\hline OO & Legal & Environmental Community Opposition & $8.5 \%$ & $39.7 \%$ \\
\hline $\mathrm{HH}$ & Finance & Capital Cost, Economy of scale & $8.1 \%$ & $47.7 \%$ \\
\hline II & Finance & Operating Costs & $8.1 \%$ & $55.8 \%$ \\
\hline PP & Corp Policy & Power Purchase Agreements & $6.5 \%$ & $62.3 \%$ \\
\hline BB & Corp Policy & Corporate Experience & $5.7 \%$ & $67.9 \%$ \\
\hline FF & Finance & Competition for Feedstock & $5.7 \%$ & $73.6 \%$ \\
\hline NN & Regulation & Permitting / Siting Problems & $5.7 \%$ & $79.3 \%$ \\
\hline QQ & Regulation & Cost of Environmental Controls & $5.1 \%$ & $84.4 \%$ \\
\hline DD & Finance & Feedstock Cost & $4.1 \%$ & $88.4 \%$ \\
\hline GG & Technology & Process Efficiency & $3.2 \%$ & $91.7 \%$ \\
\hline KK & Finance & Higher Interest Rates & $3.1 \%$ & $94.7 \%$ \\
\hline EE & Finance & Feedstock Transportation & $1.7 \%$ & $96.4 \%$ \\
\hline LL & Finance & Low Coal Prices & $1.6 \%$ & $98.0 \%$ \\
\hline RR & Technology & Technology Immaturity - Gasification & $1.5 \%$ & $99.6 \%$ \\
\hline MM & Finance & Low Oil and Gas Prices & $0.4 \%$ & $100.0 \%$ \\
\hline
\end{tabular}


Table 4: Key Success Factors, Relative to Coal and Natural Gas

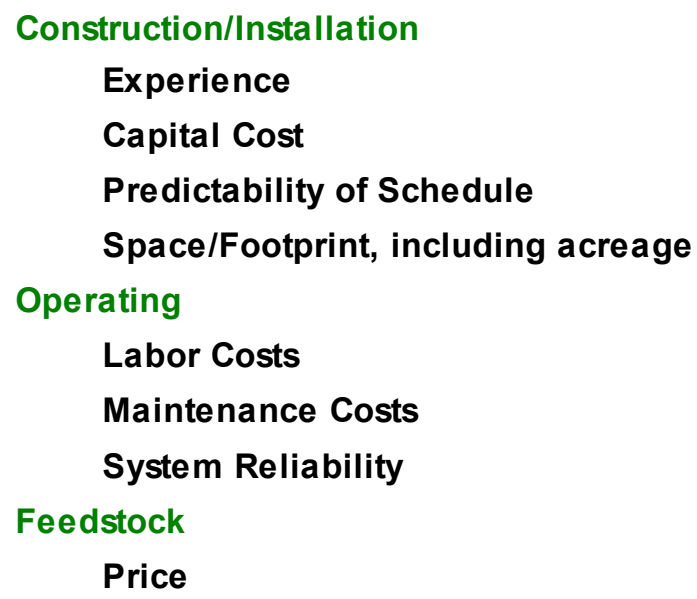

Relative to Coal Relative to N. Gas

Residues

Dedicated Feeds

Availability

Reliability of Supply

Quality

Environmental

Air Emissions

Green House Gases

Solid Wastes

Liquid Wastes

Permitting

Waste Reduction

$+/ 0 \quad 0 /-$

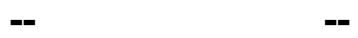

$+I-\quad+I-$
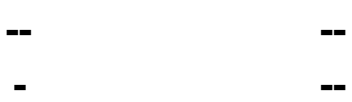

Economic

Financing

Power Purchase Agreement

Tax Incentives

Regulatory Policy

\begin{tabular}{|c|c|}
\hline NA & NA \\
\hline+ & -- \\
\hline NA & NA \\
\hline 0 & -- \\
\hline 0 & - \\
\hline 0 & - \\
\hline$=$ & - \\
\hline$+/ 0$ & $0 /-$ \\
\hline -- & -- \\
\hline$+I-$ & $+I-$ \\
\hline -- & -- \\
\hline- & -- \\
\hline+ & -- \\
\hline++ & ++ \\
\hline+ & -- \\
\hline $0 /+$ & $0 /-$ \\
\hline+ & - \\
\hline++ & ++ \\
\hline- & - \\
\hline 0 & - \\
\hline+ & + \\
\hline+ & + \\
\hline
\end{tabular}




\section{Technology Characterizations}

A series of case studies have been performed on the three conversion routes for CHP applications of biomass - direct combustion, gasification, and cofiring. The studies are based on technology characterizations developed by NREL and EPRI ${ }^{1}$, and much of the technology descriptions given here are excerpted from that report. Variables investigated include plant size and feed cost; and both cost of electricity and cost of steam are estimated using a discounted cash flow analysis.

The nearest term and lowest-cost option for the use of biomass is cofiring with coal in existing boilers. Cofiring refers to the practice of introducing biomass as a supplementary energy source in high efficiency boilers. Boiler technologies where cofiring has been practiced, tested, or evaluated, include wall- and tangentially-fired pulverized coal (PC) boilers, cyclone boilers, fluidized-bed boilers, and spreader stokers. The current coal-fired power generating system represents a direct system for carbon mitigation by substituting biomass-based renewable carbon for fossil carbon. Extensive demonstrations and trials have shown that effective substitutions of biomass energy can be made up to about $15 \%$ of the total energy input with little more than burner and feed intake system modifications to existing stations. Since large scale power boilers in the $1999345 \mathrm{GW}$ capacity fleet range from $100 \mathrm{MW}$ to $1.3 \mathrm{GW}$ the biomass potential in a single boiler ranges from $15 \mathrm{MW}$ to $150 \mathrm{MW}$. Preparation of biomass for cofiring involves well known and commercial technologies. After tuning the boiler's combustion output, there is little or no loss in total efficiency, implying that the biomass combustion efficiency to electricity would be about $33 \%-37 \%$. Since biomass in general has significantly less sulfur than coal, there is a $\mathrm{SO}_{2}$ benefit; and early test results suggest that there is also a $\mathrm{NO}_{\mathrm{x}}$ reduction potential of up to $20 \%$ with woody biomass. Investment levels are very site specific and are affected by the available space for yarding and storing biomass, installation of size reduction and drying facilities, and the nature of the boiler burner modifications. Investments are expected to be in $\$ 100$ - $\$ 700 / \mathrm{kW}$ of biomass capacity, with a median in the $\$ 180-200 / \mathrm{kW}$ range.

Another potentially attractive biopower option is based on gasification. Gasification for power production involves the devolatilization and conversion of biomass in an atmosphere of steam or air to produce a medium- or low- calorific gas. This biogas is used as fuel in a combined cycle power generation cycle involving a gas turbine topping cycle and a steam turbine bottoming cycle. A large number of variables influence gasifier design, including gasification medium (oxygen or no oxygen), gasifier operating pressure, and gasifier type. Advanced biomass power systems based on gasification benefit from the substantial investments made in coal-based gasification combined cycle (GCC) systems in the areas of hot gas particulate removal and synthesis gas combustion in gas turbines. They also leverage investments made in the Clean Coal Technology Program (commercial demonstration cleanup and utilization technologies) and in those made as part of DOE's Advanced Turbine Systems (ATS) Program. Biomass gasification systems will also stand ready to provide fuel to fuel cell and hybrid fuelcell/gas turbine systems, particularly in developing or rural areas without cheap fossil fuels or problematic transmission infrastructure. The first generation of biomass GCC systems would realize efficiencies nearly double that of the existing industry. In a cogeneration application efficiencies could exceed $80 \%$. This technology is very near to commercial availability with mid-size plants operating in Finland, the UK, the Netherlands, and Vermont. Costs of a first-of-a-kind biomass GCC plant are estimated to be in the $\$ 1,800-\$ 2,000 / \mathrm{kW}$ range with the cost dropping rapidly to the $\$ 1400 / \mathrm{kW}$ range for a mature plant in the 2010 time frame.

\footnotetext{
1 "Renewable Energy Technology Characterizations," EPRI-TR-109469, Electric Power Research Institute, Palo Alto, California, December 1997 (RETC97)
} 
Direct-fired combustion technologies are another option, especially with retrofits of existing facilities to improve process efficiency. Direct combustion involves the oxidation of biomass with excess air, giving hot flue gases which produce steam in the heat exchange sections of boilers. The steam is used to produce electricity in a Rankine cycle. In an electricity-only process, all of the steam is condensed in the turbine cycle while, in CHP operation, a portion of the steam is extracted to provide process heat. Today's biomass-fired steam cycle plants typically use single pass steam turbines. However, in the past decade, efficiency and design features, found previously in large-scale steam turbine generators, have been transferred to smaller capacity units. These designs include multi-pressure, reheat and regenerative steam turbine cycles, as well as supercritical steam turbines. The two common boiler designs used for steam generation with biomass are stationary- and traveling-grate combustors (stokers) and atmospheric fluid-bed combustors. The addition of dryers and incorporation of more-rigorous steam cycles is expected to raise the efficiency of direct combustion systems by about $10 \%$ over today's efficiency, and to lower the capital investment from the present $\$ 2,000 / \mathrm{kW}$ to about $\$ 1,275 / \mathrm{kW}$.

The three technologies are all at either the commercial scale or commercial prototype scale, and have been included in this technology case study. There are additional technologies which are at the conceptual or research and development stage and do not warrant development of a technology case study at this time, but which are potentially attractive from a performance and cost perspective and merit discussion. These technologies include biomass gasification fuel cell processes, and modular systems such as biomass gasification/Stirling engines.

A technoeconomic comparison has been made of the technologies. A listing of cases, along with technical performance is given in Table 5. Plants are defined in terms of electricity-only base cases. For example, the $25 \mathrm{MW}$ CHP case has a feed rate equal to the feed rate for a $25 \mathrm{MW}_{\mathrm{e}}$ electricity-only plant. The actual electric capacity for the $25 \mathrm{MW} \mathrm{CHP}$ case is $20.8 \mathrm{MW}_{\mathrm{e}}$, and the plant also produces 102,600 $\mathrm{lb} / \mathrm{hr}$ of $150 \mathrm{lb}$ steam. On an energy basis, the $\mathrm{H} / \mathrm{P}$ ratio is 1.44 ; and the overall $\mathrm{HHV}$ efficiency is $61 \%$.

For each of the cases, a discounted cash flow (DCF) analysis was performed. The DCF analysis was performed as a net present value (NPV) equal zero calculation, in which the internal rate of return was set at the assumed discount rate, and the cost of products varied until NPV equaled zero. Economic assumptions included $50 \%$ debt, no inflation, a $10 \%$ cost of capital, a 20 -year debt payment period, a discount rate of $20 \%$ (investment hurdle rate), a 30 -year operating life, and a capacity factor of $90 \%$. Tax rates were assumed as 35\% Federal, and 5\% State, with a combination of 7- and 20-year depreciation life (MACRS). Since CHP operations have two products, electricity and steam, a protocol for prorating values was needed. An estimate of relative market values was made using EIA ${ }^{2}$ cost of manufacturing data from 1998. Based on survey data, the EIA presented purchased electricity and steam data for the United States and census region by manufacturing sector. For this study, the average values for the chemical sector were used. Figures 5 and 6 show purchased electricity and steam costs, respectively, updated to 2001 dollars using the GDP deflator. The United States average value of industrial electricity was $\$ 0.038 / \mathrm{kWh}$ and industrial steam was $\$ 3.20 / 1,000 \mathrm{lb}$. In practice, as can be seen in the figures, the actual ratio will be site specific. When converted to a consistent set of units, the ratio of heat to power value $(\$ \mathrm{H} / \$ \mathrm{P})$ was 0.287 . The matrix of cases analyzed was relatively large. For example, for direct combustion there were four plant sizes and five feed cost levels. A graphical presentation of the results using the 0.287 ratio with electricity in $\notin / \mathrm{kWh}$ and steam in $\$ / 1,000 \mathrm{lb}$ was confusing simply because of the number of lines on each graph. In discounted cash flow analysis, if the capital and operating costs are fixed, and the discount rate is held constant, all feasible solutions give identical cash flows, e.g.

\footnotetext{
${ }^{2}$ Energy Information Agency, Department of Energy, EIA Manufacturing Consumption of Energy 1998, Table N8.3, 1998.
} 
identical incomes. Therefore, the absolute ratio of electricity and steam costs does not significantly impact the analysis. A $\$ \mathrm{H} / \$ \mathrm{P}$ value was determined, 0.341, that would simplify graphical presentation of results, and would still be realistic; this value was used for the case studies.

Table 5: Biomass Plant Technical Performance

\begin{tabular}{|c|c|c|c|c|c|}
\hline Case & $\begin{array}{c}\text { Efficiency } \\
\%\end{array}$ & $\begin{array}{c}\text { Feed Rate } \\
\text { MBtu/hr (TPH*) }\end{array}$ & $\begin{array}{c}\text { Electricity } \\
\text { MW }\end{array}$ & $\begin{array}{r}150 \mathrm{lb} \text { Steam } \\
1000 \mathrm{lb} / \mathrm{hr}\end{array}$ & $\mathbf{H} / \mathbf{P}$ \\
\hline 25 MW Electric - Direct Comb & 30 & $284(16.73)$ & 25.0 & 0 & -- \\
\hline 25 MW CHP - Direct Comb & 62 & $284(16.73)$ & 19.8 & 107 & 1.44 \\
\hline 25 MW Steam & 75 & $284(16.73)$ & -2.5 & 214 & -- \\
\hline $50 \mathrm{MW}$ Electric - Direct Comb & 30 & $569 \quad(33.45)$ & 50.0 & 0 & -- \\
\hline 50 MW CHP - Direct Comb & 62 & $569 \quad(33.45)$ & 41.5 & 214 & 1.44 \\
\hline 50 MW Steam & 75 & $569 \quad(33.45)$ & -5.0 & 429 & -- \\
\hline 75 MW Electric - Direct Comb & 30 & $853 \quad(50.18)$ & 75.0 & 0 & -- \\
\hline 75 MW CHP - Direct Comb & 62 & $853 \quad(50.18)$ & 62.2 & 321 & 1.44 \\
\hline 75 MW Steam & 75 & $853 \quad(50.18)$ & -7.5 & 643 & -- \\
\hline 100 MW Electric - Direct Comb & 30 & $1,137(66.90)$ & 100.0 & 0 & -- \\
\hline 100 MW CHP - Direct Comb & 61 & $1,137(66.90)$ & 83.0 & 428 & 1.44 \\
\hline 100 MW Steam & 75 & $1,137(66.90)$ & -10.0 & 857 & -- \\
\hline 75 MW Gasification-Electric & 36 & $711(41.80)$ & 75.0 & 0 & -- \\
\hline 75 MW Gasification - CHP & 82 & $711(41.80)$ & 59.3 & 324 & 1.60 \\
\hline $150 \mathrm{MW}$ Gasification - Electric & 36 & $711(41.80)$ & 150.0 & 0 & -- \\
\hline 150 MW Gasification - CHP & 82 & $1,422(83.60)$ & 118.6 & 648 & 1.60 \\
\hline 45 MW Cofiring CHP (15\%) & 60 & $518(30.46)$ & 41.0 & 170 & 1.21 \\
\hline 45 MW Cofiring Steam & 66 & $518(30.46)$ & -2.7 & 341 & -- \\
\hline 105 MW Cofiring CHP (15\%) & 60 & $1,208(71.08)$ & 95.7 & 397 & 1.21 \\
\hline 105 MW Cofiring Steam & 66 & $1,208(71.08)$ & -6.30 & 796 & -- \\
\hline
\end{tabular}

* Dry tons@17 MBtu/ton 
Figure 5: Chemical Industry Cost of Purchased Electricity

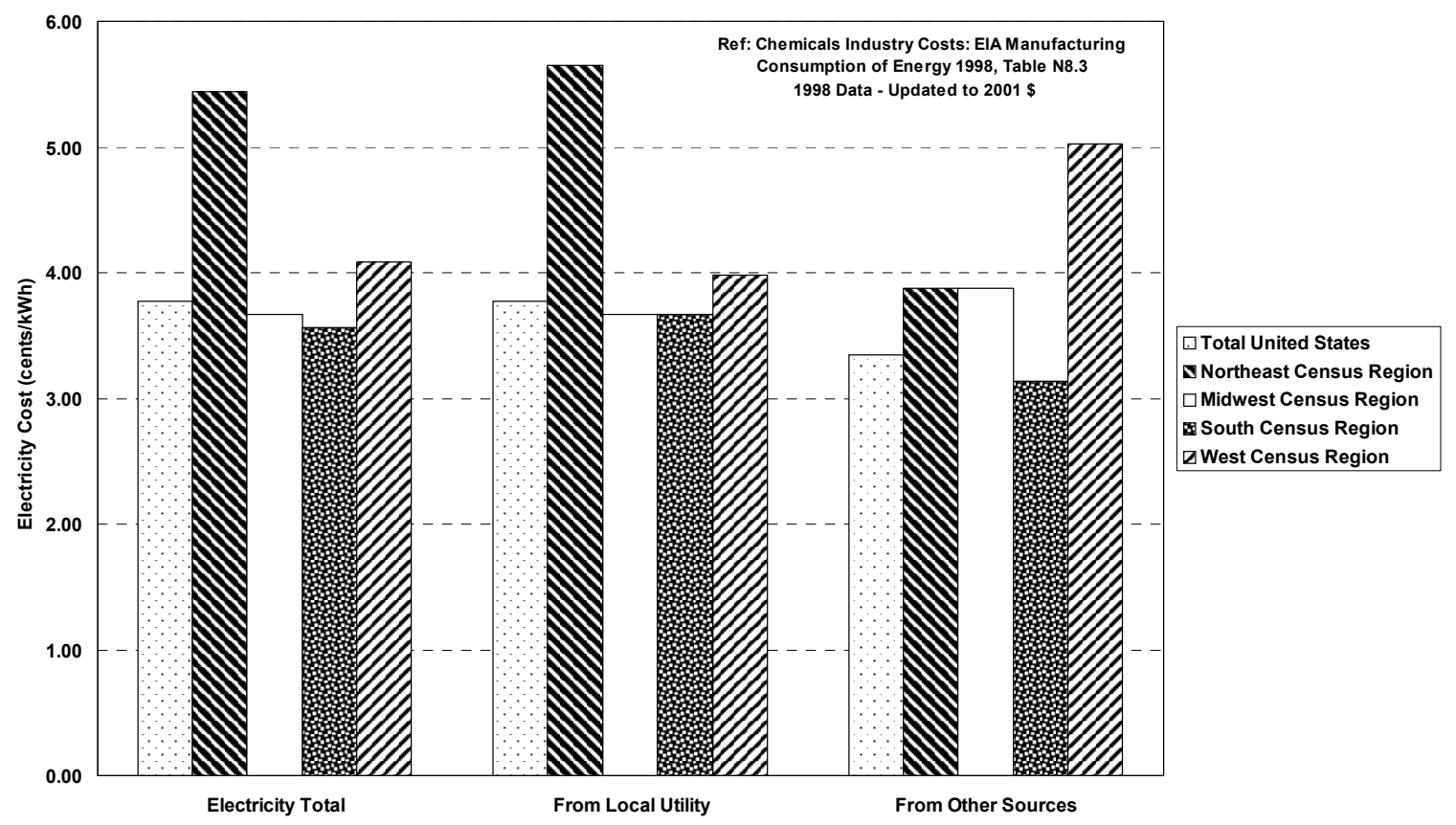

Figure 6: Chemical Industry Cost of Purchased Steam

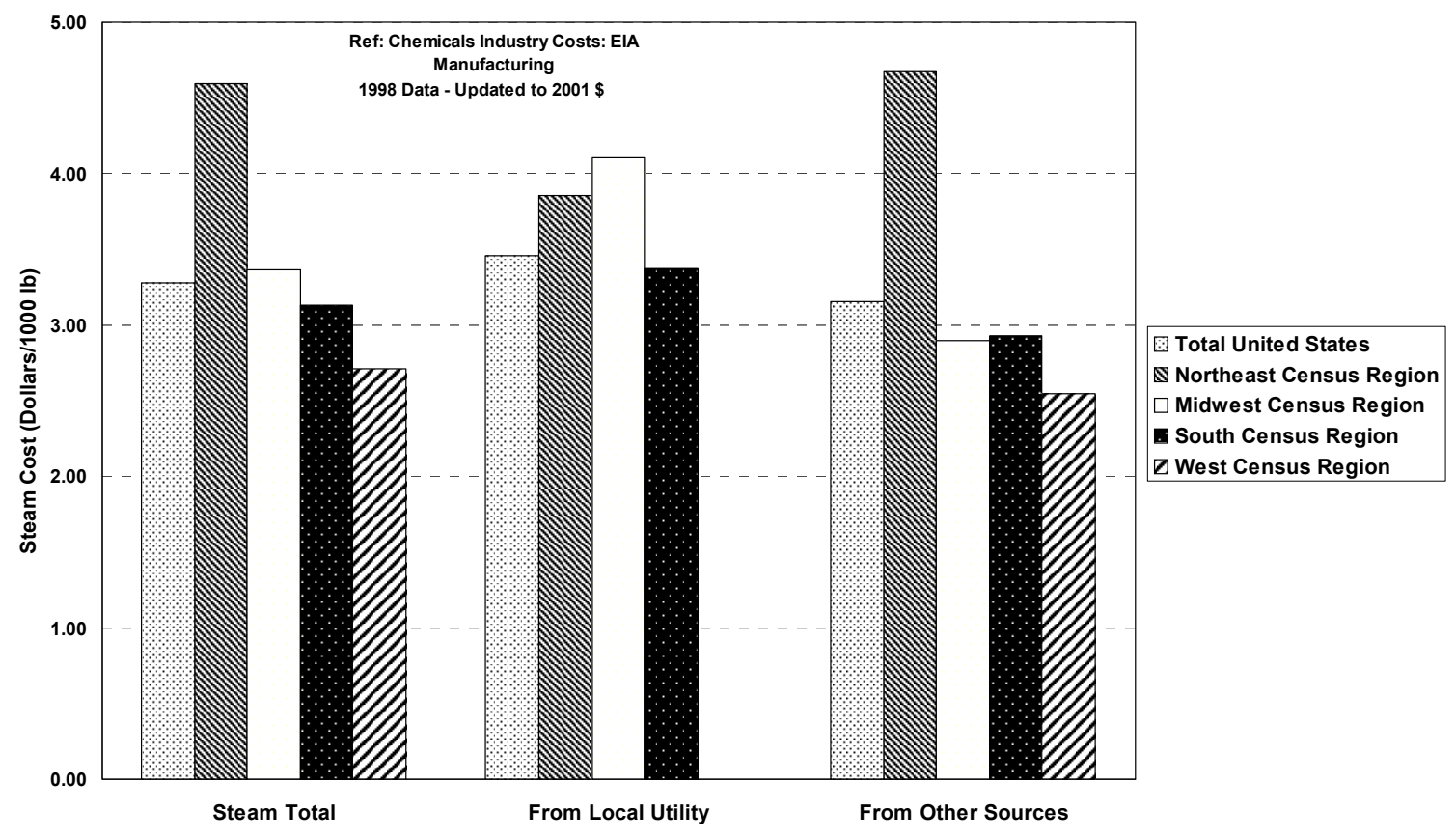


Table 6 presents a summary of capital costs, operating costs, and required cash flow or direct combustion, gasification, and cofiring. The capital investment required for cofiring is an order of magnitude less than direct combustion and gasification. Exclusive of feed costs, the operating costs range from a negative $0.23 \phi / \mathrm{kWh}$ for cofiring to $1.73 \phi / \mathrm{kWh}$ for direct combustion. At a $20 \%$ discount rate, the required cash flow for cofiring is correspondingly less.

Table 6: Cost and Required Cash Flow Summary

\begin{tabular}{|l|c|c|c|c|c|}
\hline \multicolumn{1}{|c|}{ CHP Case } & \multicolumn{2}{|c|}{ Capital Cost } & \multicolumn{2}{c|}{ Operating Cost ${ }^{(\mathrm{a})}$} & $\begin{array}{c}\text { Cumulative } \\
\text { Required } \\
\text { Cash Flow } \\
\text { Million \$ }\end{array}$ \\
& Million \$ & $\$ / \mathrm{kW}$ & $\begin{array}{c}\text { Million } \\
\$ / \mathrm{yr}\end{array}$ & $\phi / \mathrm{kWh}$ & 72 \\
\hline Cofiring - 105 MW & 16.4 & 156 & $(2.02)^{(\mathrm{b})}$ & $(0.23)^{(\mathrm{b})}$ & 479 \\
\hline $\begin{array}{l}\text { Direct Combustion - 75 } \\
\text { MW }\end{array}$ & 131.0 & 1,747 & 10.22 & 1.73 & 593 \\
\hline $\begin{array}{l}\text { Direct Combustion - 100 } \\
\text { MW }\end{array}$ & 160.5 & 1,605 & 13.49 & 1.71 & 433 \\
\hline IGCC - 75 MW & 149.3 & 2,070 & 6.71 & 1.14 & 767 \\
\hline IGCC - 150 MW & 196.7 & 1,312 & 11.75 & 0.99 & \\
\hline
\end{tabular}

(a) incremental cost

(b) exclusive of feed

A series of sensitivity studies were performed to determine the impact of feed cost, plant size, capital cost, discount rate, debt, potential carbon allowances, tax credits, and steam-only production. Four examples are presented in this summary.

\section{Feed Cost}

In Figure 7, the effect of feed cost on required electricity and steam costs is shown for all systems The negative feed cost represents residue material generated in a chemical manufacturing or other industrial facility that is presently disposed of at some net cost, and where the negative cost represents a savings in disposal cost that can be represented by a negative transfer price. The $0-1 \$ /$ ton values represent residue materials presently used (see Figure 3.1 in Chapter 3); and the higher values represent marginal costs for larger supply levels. Typically dedicated feeds will only be available at $>\$ 3 / \mathrm{MBtu}$. The results show that all combustion CHP cases give required product costs greater than existing industrial market prices. The gasification plants show a comparable trend, but with required product costs 2 to $3 \notin / \mathrm{kWh}$ (\$2-\$3/1,000 lb steam) lower than the direct combustion cases. Gasification CHP using technology presently available, i.e., $1^{\text {st }}$ generation commercial systems, may be competitive with existing sources of industrial electricity and steam if a manufacturing facility has an internal source of waste available. For higher cost residues or dedicated crops, incentives or more advanced technologies, i.e. nth plant technology with higher efficiency, will be required to reduce product costs to a competitive level. Cofiring represents fuel substitution for existing coal feed. The coal savings offsets the required capital investment and the incremental cost of cofiring reflects the cost of biomass feed. 


\section{Plant Size}

Figure 8 shows the effect of plant size on required product cost for the base feed cost of \$2/MBtu. Capital and operating costs were scaled using a 0.7 scaling factor. The rationale for the scaling factor was discussed earlier in the direct-fired biomass section. Since only two plant sizes were calculated for gasification and cofiring, the shape of the curve is not apparent, but would follow the same trend if more sizes were estimated. The cost of electricity (steam) for direct combustion varied from $10.6 \phi / \mathrm{kWh}$ $\left(\$ / 1,000 \mathrm{lb}\right.$ steam) at $25 \mathrm{MW}_{\text {eq }}$ to $8.4 \notin / \mathrm{kWh}\left(\$ / 1,000 \mathrm{lb}\right.$ steam) at $100 \mathrm{MW}_{\text {eq }}$. Gasification production costs were $6.7 \phi / \mathrm{kWh}\left(\$ / 1000 \mathrm{lb}\right.$ steam) at $75 \mathrm{MW}_{\text {eq }}$ and $6.1 \phi / \mathrm{kWh}(\$ / 1,000 \mathrm{lb}$ steam) at $150 \mathrm{MW}$. For cofiring at $15 \%$ the incremental costs were $2.2 \varnothing / \mathrm{kWh}\left(\$ / 1,000 \mathrm{lb}\right.$ steam) for $45 \mathrm{MW}_{\text {eq }}$ biomass and $2.1 \phi / \mathrm{kWh}(\$ / 1,000 \mathrm{lb}$ steam $)$ for $105 \mathrm{MW}_{\mathrm{eq}}$ biomass.

\section{Discount Rate}

The base case study uses a 20 percent discount rate, but allowable discount rate is dependent on the individual organization performing the evaluation. NREL typically uses $15 \%$ for analyses, and EPRI has used $10.8 \%$ for utility cash flow comparisons (EPRI TAG, 1993). Therefore, a set of sensitivity cases was performed to look at the sensitivity to discount rate over the range 10\%-25\%. The results are given in Figure 9. Over the range of $10 \%$ to $25 \%$, the $100 \mathrm{MW}_{\text {eq }}$ direct combustion CHP system cost varies from $6.4 \phi / \mathrm{kWh}\left(\$ / 1,000 \mathrm{lb}\right.$ steam) to $9.6 \phi / \mathrm{kWh}$, the $150 \mathrm{MW}_{\text {eq }}$ gasification CHP cost varies from $4.5 \phi / \mathrm{kWh}$ to $7.0 \phi / \mathrm{kWh}$, and the $105 \mathrm{MW}_{\text {eq }}$ cofiring CHP cost varies from $1.9 \phi / \mathrm{kWh}$ to $2.2 \phi / \mathrm{kWh}$.

\section{Tax Credit}

Various proposals are before Congress to modify and expand the definition of the IRS, Section 49 "closed loop" biomass tax credit to include residues and cofiring. Therefore, estimates of the impact of such tax credits were made. The estimates were made using two assumptions-a project basis and a corporate basis. Using the project basis assumption only project generated taxable income is used. In this case, the capital equipment depreciation in the early years of the project greatly limits taxable income, and the impact of a tax credit is small. For the corporate basis cases, the assumption is made that the corporation has other taxable income that the tax credit can be applied against so that all potential tax credit can be used. Other assumptions are that the tax credit is available for $100 \%$ of the net plant production, i.e, that the net production of electricity is sold; and that the tax credit applies for 10 years of plant operation.

Figure 10 shows the impact of a electricity production tax credit on the required cost of production of electricity for direct combustion CHP and for gasification CHP. For the $100 \mathrm{MW}_{\text {eq }}$ direct combustion system, the impact on electricity (steam) cost of production with a $1 \notin / \mathrm{kWh}$ production credit is minus $0.36 \varnothing / \mathrm{kWh}(\$ / 1,000 \mathrm{lb}$ steam) for a project basis and minus $0.77 \phi / \mathrm{kWh}$ for a corporate basis; with a $2 \phi / \mathrm{kWh}$ production credit, the respective values are minus $0.57 \phi / \mathrm{kWh}$ and minus $1.51 \phi / \mathrm{kWh}$. For the $150 \mathrm{MW}_{\text {eq }}$ gasification CHP system with a $1 \varnothing / \mathrm{kWh}$ production credit, the cost of production is lowered by 0.42 and $0.81 \phi / \mathrm{kWh}$ for the project and corporate cases, respectively; for a $2 \phi / \mathrm{kWh}$ production credit, the respective cost of production reduction is 0.50 and $1.57 \phi / \mathrm{kWh}$.

Comparable estimates can be made for the cofiring CHP cases, but the analysis is somewhat more complicated. Figure 11 shows the impact of a production credit on $15 \%$ cofiring CHP incremental costs. For the project cases, the decrease in cost of production for the 45 and $105 \mathrm{MW}_{\text {eq }}$ plants reaches a maximum of about $0.07 \varnothing / \mathrm{kWh}$ at a tax credit of about $0.5 \phi / \mathrm{kWh}$. For the corporate analysis, the NPV calculation does not give meaningful results above a tax credit level of $0.5 \phi / \mathrm{kWh}$. At this level the reduction is about $0.40 \phi / \mathrm{kWh}$ for both plants sizes. Above this level, a NPV calculation can be made but to satisfy the $20 \%$ return constraint, a solution is obtained that gives negative cash flows in the years after expiration of the tax credit. This indicates that the 10-year production tax credit has a large impact on potential project rate of return. A return on investment (ROI) estimate was made to show the impact of the production tax credit, assuming a fixed cost of production (see Figure 12). For this example, the incremental cost of production of electricity (steam) was set at $2.0 \phi / \mathrm{kWh}(\$ 2 / 1,000 \mathrm{lb}$ steam), and the 
10 -year production tax credit varied from 0 to $1 \phi / \mathrm{kWh}$. For the $45 \mathrm{MW}_{\text {eq }}$ plant, the ROI varies from $13.6 \%$, to $31.6 \%$, to $47.8 \%$ at a $0,0.5$, and $1 \phi / \mathrm{kWh}$ tax credit, respectively. The comparable ROIs for the $105 \mathrm{MW}_{\text {eq }}$ case are $17.0,38.6$, and $57.5 \%$.

Figure 7: Biomass CHP - Sensitivity to Feed Cost

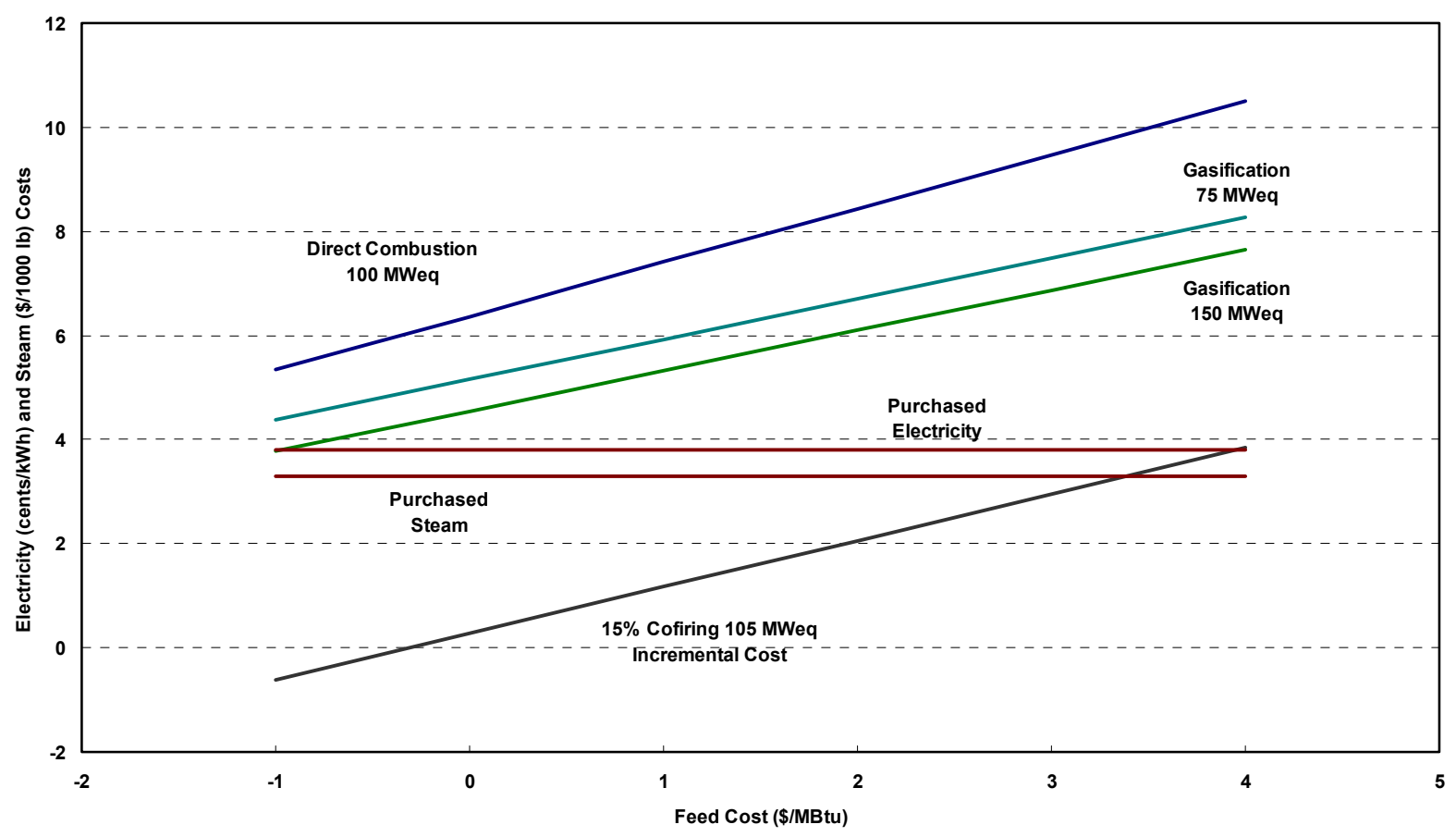


Figure 8: Biomass CHP - Effect of Plant Size on Cost of Electricity and Steam

Feed Cost $=\$ 2 / \mathrm{MBtu}$

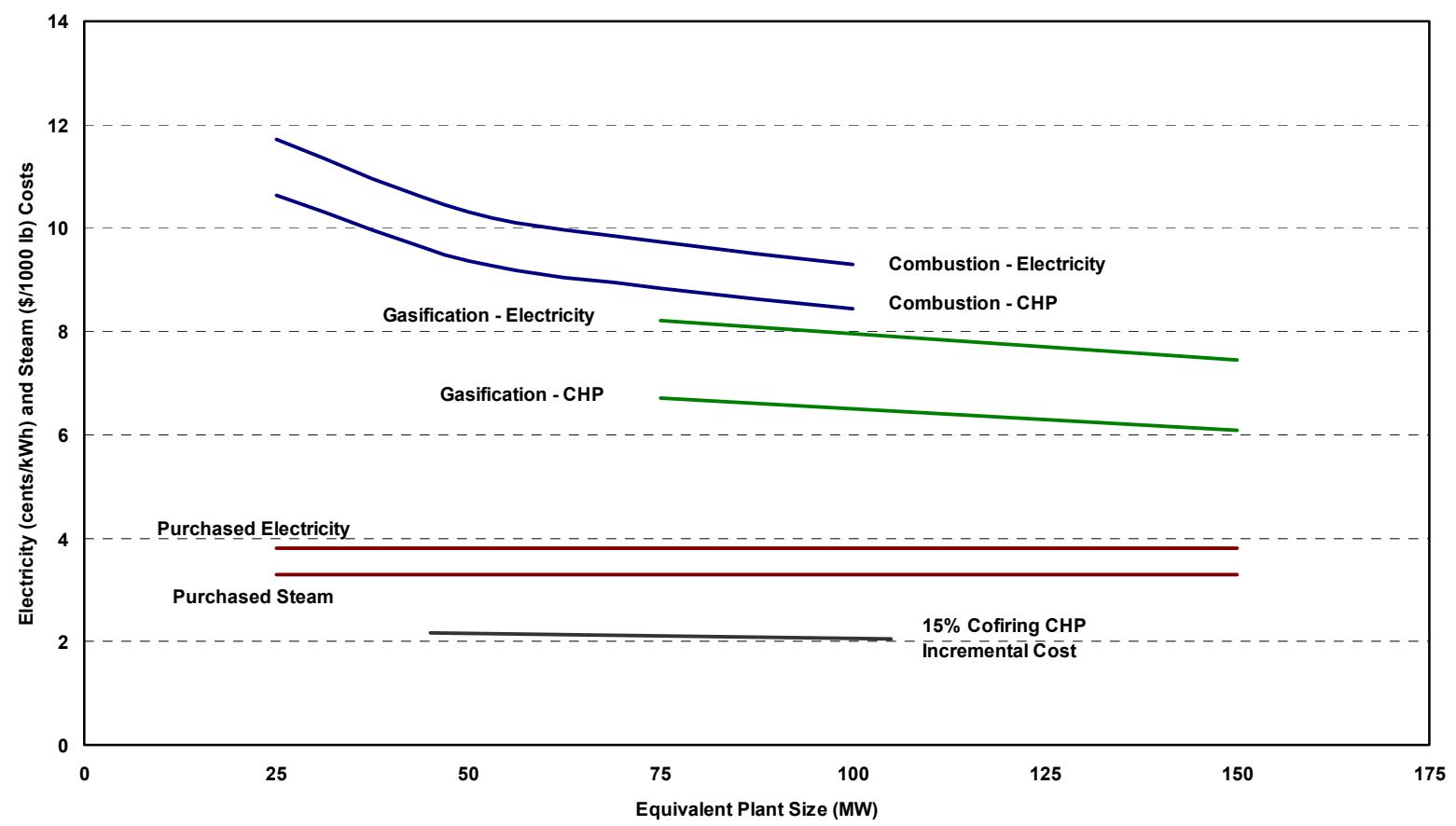

Figure 9: Biomass CHP - Sensitivity to Discount Rate

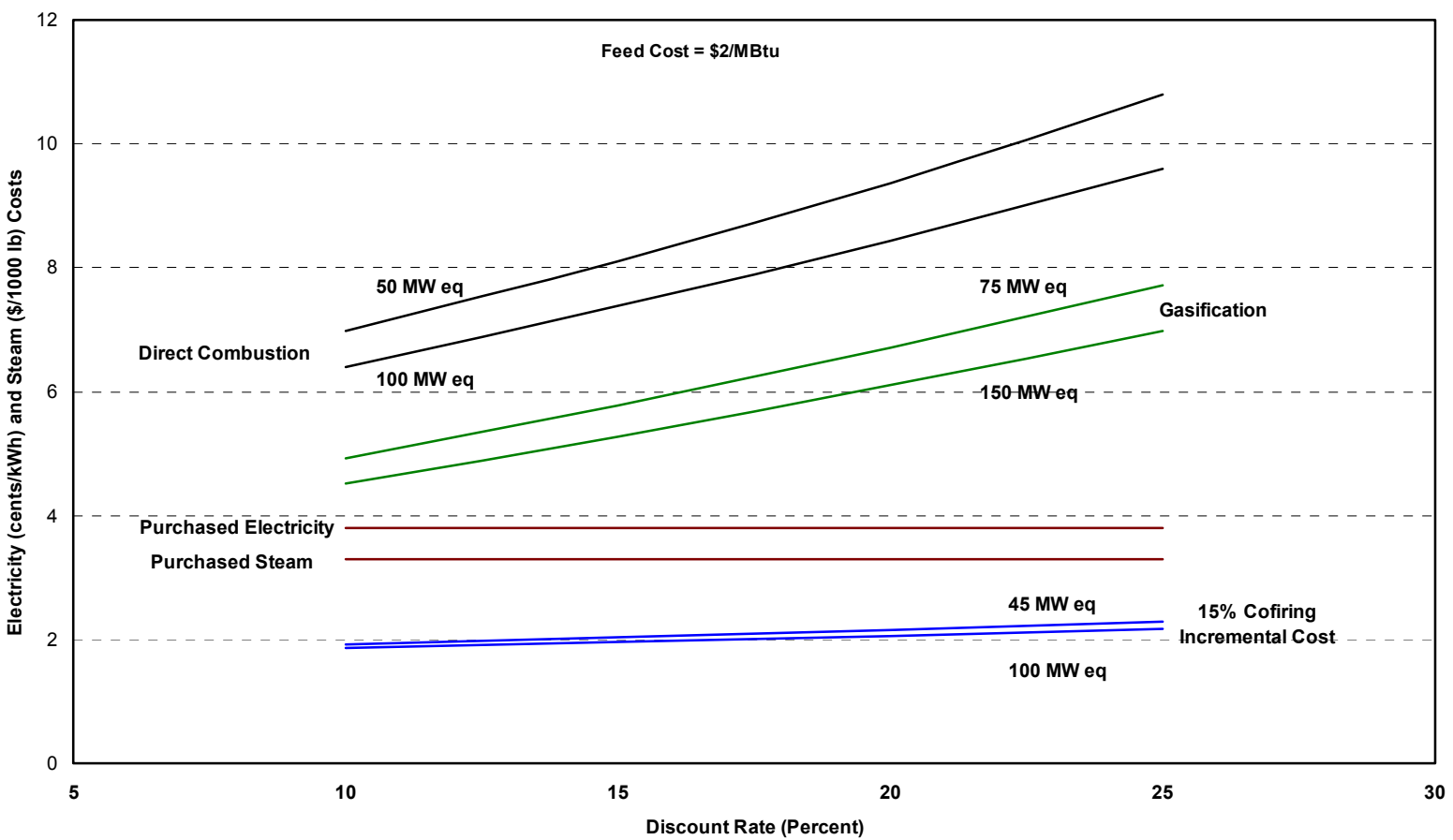


Figure 10: Biomass Combustion and Gasification CHP Impact of Tax Credit

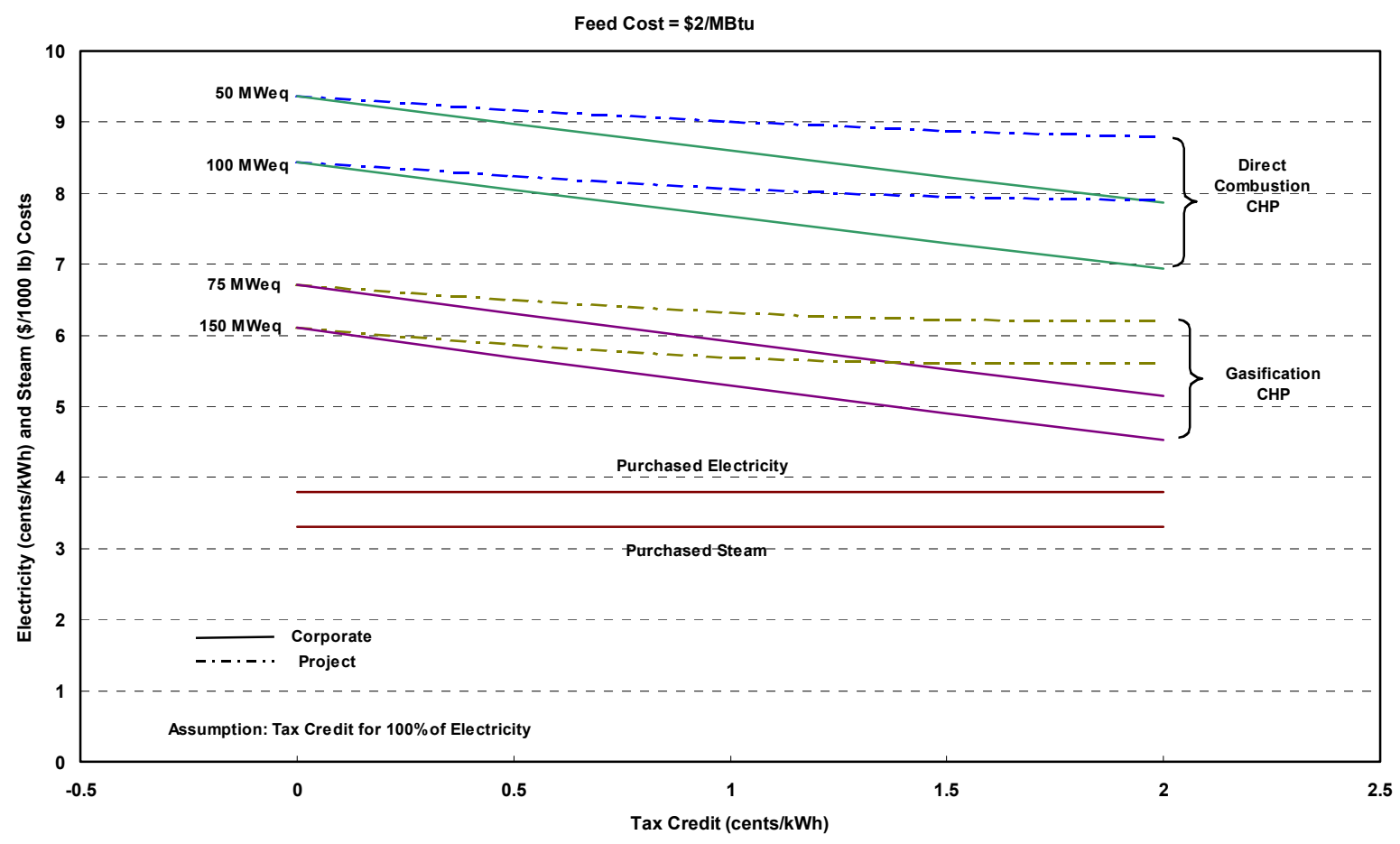

Figure 11: Biomass Cofiring CHP Incremental Costs, Im pact of Tax Credit

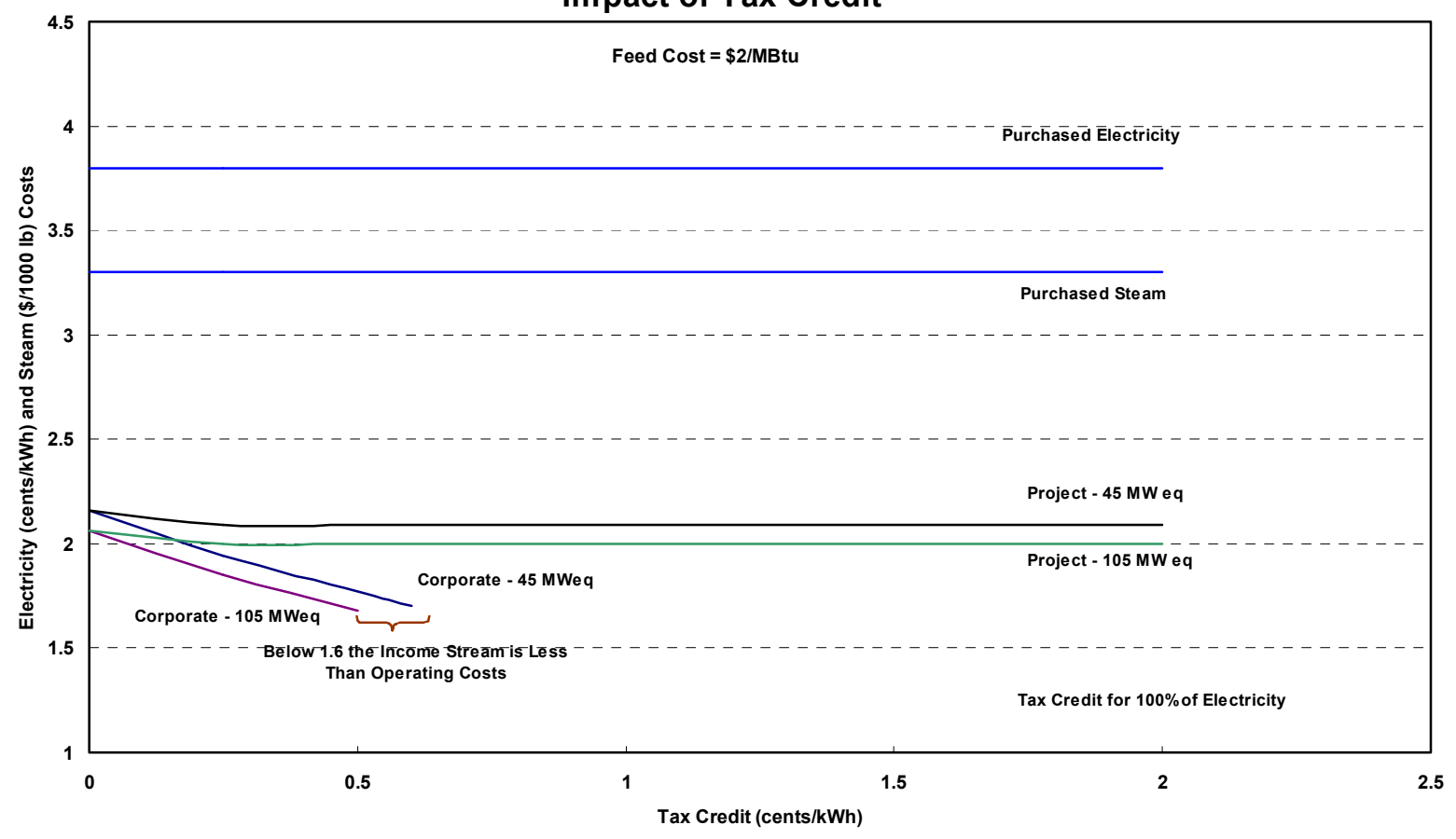




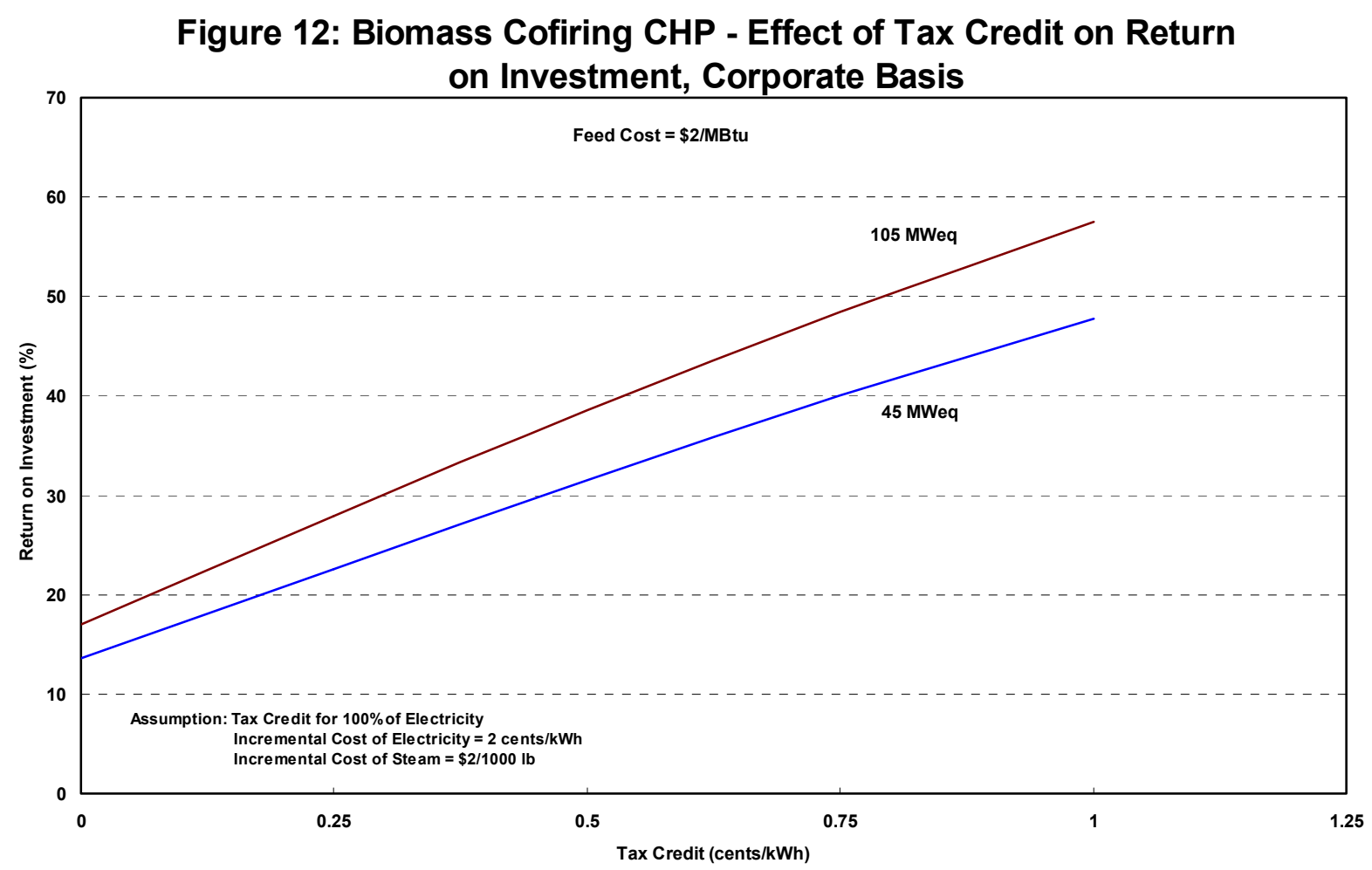

\section{Environmental Performance}

Two issues that could create tremendous opportunities for biomass are global warming and the implementation of Phase II of Title IV of the Clean Air Act Amendments of 1990 (CAAA). Biomass offers the benefit of reducing $\mathrm{NO}_{x}, \mathrm{SO}_{2}$, and $\mathrm{CO}_{2}$ emissions. The environmental benefits of biomass technologies are among its greatest assets. Global warming is gaining greater acceptance in the scientific community. There now appears to be a consensus among the world's leading environmental scientists and informed individuals in the energy and environmental communities that there is a discernable human influence on the climate; and that there is a link between the concentration of carbon dioxide (i.e., greenhouse gases) and the increase in global temperatures. Biomass use can play an essential role in reducing greenhouse gases, thus reducing the impact on the atmosphere. Cofiring biomass and fossil fuels and the use of integrated biomass gasification combined cycle systems can be an effective strategy for electric utilities to reduce their emissions of greenhouse gases.

\section{Emissions}

Biopower is unique among renewable energy sources because it involves combustion that releases air pollutants. Major emissions of concern from biopower plants are particulate matter (PM), carbon monoxide $(\mathrm{CO})$, volatile organic compounds $(\mathrm{VOC})$, and nitrogen oxides $\left(\mathrm{NO}_{\mathrm{x}}\right)$. Biopower sulfur dioxide emissions are typically low because of the low amount of sulfur usually found in biomass. Actual amounts and the type of air emissions depend on several factors, including the type of biomass combusted, the furnace design, and operating conditions. 
Table 7compares air emissions from biomass facilities, using different feedstocks and boilers, with representative coal and natural gas systems. When comparing emissions it very important to understand that all the power systems reported-both fossil and biomass-meet the air emission standards governing permitting and operation in effect when the facilities were constructed, and represent not only differences in fuel, but also differences in emission control systems. Future systems will meet the emissions standards in place at the time of permitting, and choices of system and fuel will largely be governed by costs associated with meeting those standards.

Permits for biomass combustion facilities constructed in the 1980s and 1990s focused primarily on PM emissions, although $\mathrm{NO}_{\mathrm{x}}$ and $\mathrm{CO}$ emissions were also regulated. Pollution control consisted of bag houses or electrostatic precipitators to remove particulates, with $\mathrm{NO}_{\mathrm{x}}$ and $\mathrm{CO}$ emissions controlled primarily by fuel input control, fuel firing, and boiler operations. In regions that were not in compliance with $\mathrm{NO}_{\mathrm{x}}$ levels, ammonia or urea was added to the flue gas to reduce $\mathrm{NO}_{\mathrm{x}}$ emissions by another 33 to 75 percent. More than 90 million Americans are living in regions that are not meeting one or more air emission standards under the CAA.[9] As a result, newer biomass facilities generally will have to meet stricter air emission controls using Best Available Control Technologies (BACT) for pollutants in regions that are in compliance with the CAA, and Lowest Available Emissions Reduction (LAER) for pollutants in regions that are not in compliance with the CAA.

Table 8 presents averaged permitted and actual emission levels from 34 operating wood-fired generating plants in California. Of these, 23 are spreader stoker facilities and 11 are FBCs. These facilities were built prior to the new emissions standards. New facilities are subject to the new and much stricter Clean Air Act emissions standards. Air emission standards for the most recently constructed stand-alone biomass plant in the New England region, Pine Tree Power in Westminster, Massachusetts are included for comparison. This facility was permitted to burn clean construction/demolition wood and has the most restrictive permit conditions of any wood-fired power plant in New England. The facility can meet these requirements using a high-efficiency fluidized bed boiler (low CO and VOC emissions), an SNCR system for NOx reduction, and a mechanical collector and baghouse for particulate control. $\mathrm{No}_{2} \mathrm{SO}_{2}$ controls are required.

A number of states-including Texas, California, and Connecticut-have enacted or are considering type certification standards for distributed generation units less than $50 \mathrm{MW}_{\mathrm{e}}$ to ensure that emissions from small electric generating units to do not exceed BACT standards for central generating stations, and to simplify and reduce the time and cost of permitting such units. The majority of existing biopower plants would be covered by such standards if permitted today.

The Texas air quality standard became effective in 2001 for distributed generation units less than $50 \mathrm{MW}_{\mathrm{e}}$ to provide a streamlined permitting method to encourage the use of clean electric generating units. The standard provides a certification method for emissions based on reference test results The standard only requires certification of $\mathrm{NO}_{\mathrm{x}}$ under the decision that $\mathrm{CO}$ and $\mathrm{VOC}$ emissions will controlled if the $\mathrm{NO}_{\mathrm{x}}$ limits are reached. Units that use combined heat and power may take credit for heat at a rate of $1 \mathrm{MWh}$ for each 3.4 million Btu if the heat recovered is greater than $20 \%$ of the total CHP output. A summary of emission limits are given in Table 9. 
Table 7: Direct Air Emissions from Wood Residue Facilities by Boiler Type Compared with Certain Fossil Fuel Technologies

(Ibs / MWh)

\begin{tabular}{|c|c|c|c|c|c|}
\hline & $\mathrm{SO}_{\mathrm{x}}$ & $\mathrm{NO}_{\mathrm{X}}$ & $\mathrm{CO}$ & PM-10 ${ }^{1}$ & Comments \\
\hline \multicolumn{6}{|c|}{ Biomass Technology } \\
\hline \begin{tabular}{|l|} 
Stoker Boiler, \\
Wood Residues $(1,4)$
\end{tabular} & 0.08 & $\begin{array}{c}2.1 \\
\text { (biomass type } \\
\text { not specified) }\end{array}$ & $\begin{array}{c}12.2 \\
\text { (biomass type } \\
\text { not specified) }\end{array}$ & $\begin{array}{c}0.50 \\
\text { (total particulates) } \\
\text { (biomass type } \\
\text { not specified) }\end{array}$ & $\begin{array}{l}\text { Based on } 23 \text { California grate } \\
\text { boilers, except for } \mathrm{SO}_{2} \\
\text { (uncontrolled) }\end{array}$ \\
\hline \begin{tabular}{|l} 
Fluidized Bed, \\
Biomass (4)
\end{tabular} & $\begin{array}{c}0.08 \\
\text { (biomass type } \\
\text { not specified) }\end{array}$ & $\begin{array}{c}0.9 \\
\text { (biomass type } \\
\text { not specified) }\end{array}$ & $\begin{array}{c}0.17 \\
\text { (biomass type } \\
\text { not specified) }\end{array}$ & $\begin{array}{c}0.3 \\
\text { (total particulates) } \\
\text { (biomass type } \\
\text { not specified) } \\
\end{array}$ & $\begin{array}{c}\text { Based on } 23 \text { California grate } \\
\text { boilers. }\end{array}$ \\
\hline $\begin{array}{l}\text { Energy Crops } \\
\text { (Poplar) } \\
\text { Gasification } \\
(a, b)\end{array}$ & \begin{tabular}{|c|}
0.05 \\
(suggested value \\
based on SOx numbers \\
for Stoker and FBC, \\
adjusted by a factor of \\
$9,180 / 13,800$ to account \\
for heat rate \\
improvement)
\end{tabular} & $\begin{array}{c}1.10 \text { to } 2.2 \\
\text { (0.66 to } 1.32 \mathrm{w} / \mathrm{SNCR} ; \\
0.22 \text { to } 0.44 \mathrm{w} \text { ith SCR) } \\
\end{array}$ & 0.23 & $\begin{array}{c}0.01 \\
\text { (total } \\
\text { particulates) }\end{array}$ & $\begin{array}{c}\text { Combustor flue gas goes } \\
\text { through cyclone and } \\
\text { baghouse. Syngas goes } \\
\text { through scrubber and } \\
\text { baghouse before gas turbine. } \\
\text { No controls on gas turbine. }\end{array}$ \\
\hline \multicolumn{6}{|l|}{ Coal Technology } \\
\hline \begin{tabular}{|l|} 
Bituminous Coal, \\
Stoker Boiler (f)
\end{tabular} & $\begin{array}{c}20.2 \\
1 \mathrm{wt} \% \mathrm{~S} \text { coal }\end{array}$ & 5.8 & 2.7 & 0.62 & $\begin{array}{l}\text { PM Control only } \\
\text { (baghouse) }\end{array}$ \\
\hline $\begin{array}{l}\text { Pulverized Coal } \\
\text { Boiler (d) }\end{array}$ & 14.3 & 6.89 & 0.35 & $\begin{array}{c}0.32 \\
\text { (total particulates) }\end{array}$ & $\begin{array}{l}\text { Average US PC boiler } \\
\text { (typically:baghouse, } \\
\text { limestone FGC) }\end{array}$ \\
\hline $\begin{array}{l}\text { Cofiring 15\% Biomass } \\
\text { (d2) }\end{array}$ & 12.2 & 6.17 & 0.35 & $\begin{array}{c}0.32 \text { (total } \\
\text { particulates) }\end{array}$ & $?$ \\
\hline \begin{tabular}{|l} 
Fluidized Bed, \\
Coal (f)
\end{tabular} & $\begin{array}{c}3.7(1 \mathrm{wt} \% \mathrm{~S} \text { coal } \\
\mathrm{Ca} / \mathrm{S}=2.5)\end{array}$ & 2.7 & 9.6 & 0.30 & $\begin{array}{l}\text { Baghouse for PM Control, } \mathrm{Ca} \\
\text { sorbents used for } \mathrm{SO}_{x}\end{array}$ \\
\hline \multicolumn{6}{|c|}{ Natural Gas Technology } \\
\hline \begin{tabular}{|l|} 
4-Stroke NG \\
Reciprocating \\
Engine (g)
\end{tabular} & 0.006 & $\begin{array}{c}\text { 7.96-38.3 } \\
\text { (depends on load } \\
\text { and air:fuel ratio) }\end{array}$ & $\begin{array}{c}\text { 2.98-35.0 } \\
\text { (depends on load } \\
\text { and air:fuel ratio) }\end{array}$ & $\begin{array}{c}\text { 0.09-0.18 } \\
\text { (depends on load } \\
\text { and air:fuel ratio) }\end{array}$ & $\begin{array}{l}\text { No control except } \\
\text { PCC at high-end of } \\
\text { PM-10 range }\end{array}$ \\
\hline $\begin{array}{l}\text { Natural Gas } \\
\text { Turbine (e) }\end{array}$ & $\begin{array}{c}0.009 \\
(0.0007 \mathrm{wt} \% \mathrm{~S})\end{array}$ & 1.72 & 0.4 & $\begin{array}{c}.09 \\
\text { (total particulates) }\end{array}$ & $\begin{array}{l}\text { Water-steam } \\
\text { injection only }\end{array}$ \\
\hline \begin{tabular}{|l|} 
Natural Gas \\
Combined Cycle $(c, e)$
\end{tabular} & 0.004 & $\begin{array}{c}0.91 \\
(0.21 \mathrm{w} / \mathrm{SCR})\end{array}$ & 0.06 & $\begin{array}{c}0.14 \\
\text { (total particulates) }\end{array}$ & $\begin{array}{l}\text { Water-steam } \\
\text { injection only }\end{array}$ \\
\hline
\end{tabular}

Table 8: Air Pollutant Emissions Limits for Biomass Power Plants (Ib/MWh)

\begin{tabular}{|c|c|c|c|c|c|c|c|c|c|}
\hline & \multirow{2}{*}{$\begin{array}{l}\text { Boiler } \\
\text { Type }\end{array}$} & \multicolumn{2}{|c|}{$\mathrm{SO}_{2}$} & \multicolumn{2}{|c|}{ NOx } & \multicolumn{2}{|c|}{$\mathrm{CO}$} & \multicolumn{2}{|c|}{ PM } \\
\hline & & Permitted & Measured & Permitted & Measured & Permitted & Measured & Permitted & Measured \\
\hline \multirow{3}{*}{$\begin{array}{l}\text { Existing California } \\
\text { Biomass Facilities }^{1}\end{array}$} & All & 1.0 & 0.08 & 2.2 & 1.7 & 9.6 & 8.6 & 0.7 & 0.4 \\
\hline & Stokers & 0.8 & 0.08 & 2.6 & 2.1 & 13.6 & 12.2 & 0.8 & 0.5 \\
\hline & FBCs & 1.4 & 0.08 & 1.3 & 0.8 & 1.7 & 0.2 & 0.5 & 0.3 \\
\hline $\begin{array}{c}\text { New } \\
\text { Massachussetts } \\
\text { Biomass Facility }{ }^{2}\end{array}$ & FBC & $\begin{array}{c}0.78 \\
(\mathrm{BACT})\end{array}$ & $\mathrm{N} / \mathrm{A}$ & $\begin{array}{c}0.74 \\
(\text { LAER) }\end{array}$ & $\mathrm{N} / \mathrm{A}$ & $\begin{array}{c}0.88 \\
(\mathrm{BACT})\end{array}$ & $\mathrm{N} / \mathrm{A}$ & $\begin{array}{c}0.20 \\
(\mathrm{BACT})\end{array}$ & N/A \\
\hline
\end{tabular}

${ }_{1}^{1}$ [4air] Data averaged for 34 California biomass facilities (23 stokers and 11 FBCs). Based on a heating value for biomass of 8,293 BTU/b, and an average heat rate of $13,800 \mathrm{BTU} / \mathrm{kWh}$.

${ }^{2}$ [2air]Permitted emissions levels for new Pine Tree Biomass Pow er Plant in Westminster, MA. BACT=Best Available Control Technology; LAER=Low est Achievable Emissions Rate 
Table 9: Texas Distributed Generation Certification Standards

\begin{tabular}{|lllll|}
\hline Size & Area & $>300$ hours per year & $<300$ hours per year & Landfill gas, digester gas \\
$>10 \mathrm{MW}$ & All & $0.14 \mathrm{lb} \mathrm{NO}_{\mathrm{x}} / \mathrm{MWh}$ & $0.38 \mathrm{lb} \mathrm{NO}_{\mathrm{x}} / \mathrm{MWh}$ & $\left.1.77 \mathrm{lb} \mathrm{NO}_{\mathrm{x}} / \mathrm{MWh}^{\mathrm{a}} \mathrm{a}\right)$ \\
& & & \\
$<10 \mathrm{MW}$ & East Texas & $0.44 \mathrm{lb} \mathrm{NO}_{\mathrm{x}} / \mathrm{MWh}(\mathrm{b})$ & \\
& & $0.14 \mathrm{lb} \mathrm{NO}_{\mathrm{x}} / \mathrm{MWh}(\mathrm{c})$ & \\
& & $1.6 \mathrm{lb} \mathrm{NO}_{\mathrm{x}} / \mathrm{MWh}$ & $21 \mathrm{lb} \mathrm{NO}_{\mathrm{x}} / \mathrm{MWh}$ & \\
\hline $10 \mathrm{MW}$ & West Texas &
\end{tabular}

(a) must contain less than 1.5 grains of $\mathrm{H}_{2} \mathrm{~S}$ or 30 grains of total sulfur

(b) prior to December 31, 2004

(c) after January 1, 2005

California has issued a draft standard, effective January 1, 2003, for any distributed generation system sold, leased, or offered for sale or lease, for use or operation in the State of California. CHP units may take credit for heat recovery if the unit achieves a minimum efficiency of 60 percent (useful energy out/fuel in). A summary of the proposed standard is given in Table 10.

Table 10: Proposed California Distributed Generation Certification Standards.

\begin{tabular}{|lccc|}
\hline Pollutant & & Emission Standard (lb/MWh) & \\
& Power Only, Jan 2003 - Dec & CHP, Jan 2003 - Dec 2006 & All Units, After Jan 1, 2007 \\
$\mathrm{NO}_{\mathrm{x}}$ & 2006 & 0.7 & 0.05 \\
$\mathrm{CO}$ & 0.5 & 6.0 & 0.08 \\
VOCs & 6.0 & 1.0 & 0.02 \\
\hline
\end{tabular}

To evaluate the potential of biopower systems a simple analysis has been performed to compare existing and potential biopower system performance relative to the proposed standards. $\mathrm{NO}_{\mathrm{x}}$ emissions for existing systems are given in Figure 13 on both a life cycle and point-source plant emission basis. A national average coal station has $\mathrm{NO}_{\mathrm{x}}$ emissions of about $6.75 \mathrm{lb} \mathrm{NO} / \mathrm{MWh}$, a NSPS coal plant emits 4.5 lb $\mathrm{NO}_{\mathrm{x}} / \mathrm{MWh}$, a natural gas combined cycle plant emits $0.2 \mathrm{lb} \mathrm{NO} / \mathrm{MWh}$, and a biopower direct combustion system emits $1.2 \mathrm{lb} \mathrm{NO} / \mathrm{MWh}$.

The potential for a CHP system to meet standards is shown in Figure 14. An existing system with flue gas recycle (FGR) has emissions of about $1.4 \mathrm{lb} \mathrm{NO} / \mathrm{MWh}$. Since FGR and selective catalytic reduction (SCR) are additive, SCR is also used, assuming an additional $80 \%$ reduction. This lowers the $\mathrm{NO}_{\mathrm{x}}$ to about $0.25 \mathrm{lb} \mathrm{NO}_{\mathrm{x}} / \mathrm{MWh}$. CHP is then assumed (60\% total efficiency, bringing the level down to 0.12 $\mathrm{lb} \mathrm{NO}_{\mathrm{x}} / \mathrm{MWh}$. The existing system meets the West Texas standard, and the CHP system with both FGR and SCR meets the East Texas standard. The system with FGR and SCR meets the 2003 California standard, but additional optimization would be required for the CHP system to meet the 2007 California standard. 


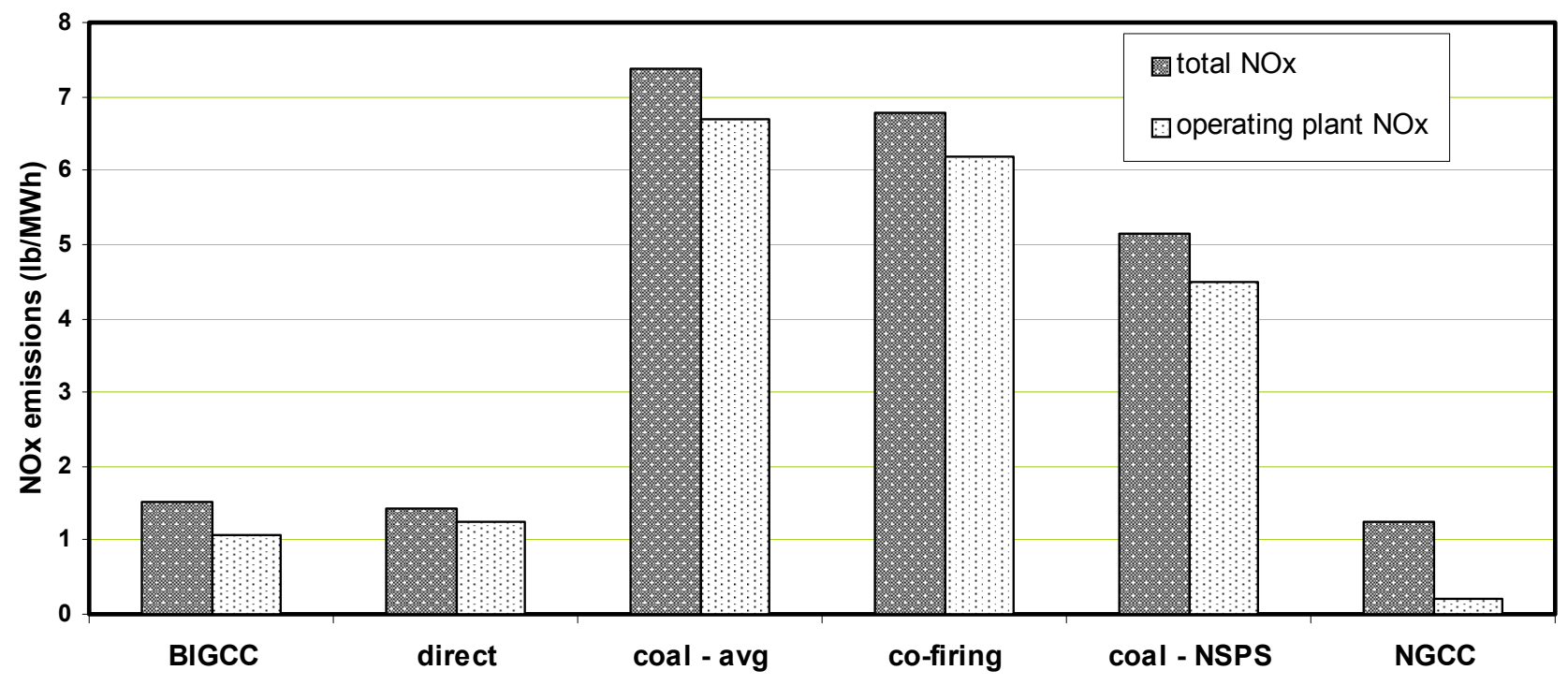

Figure 13: NOx Emissions - Life Cycle Total and Plant Operating Emissions

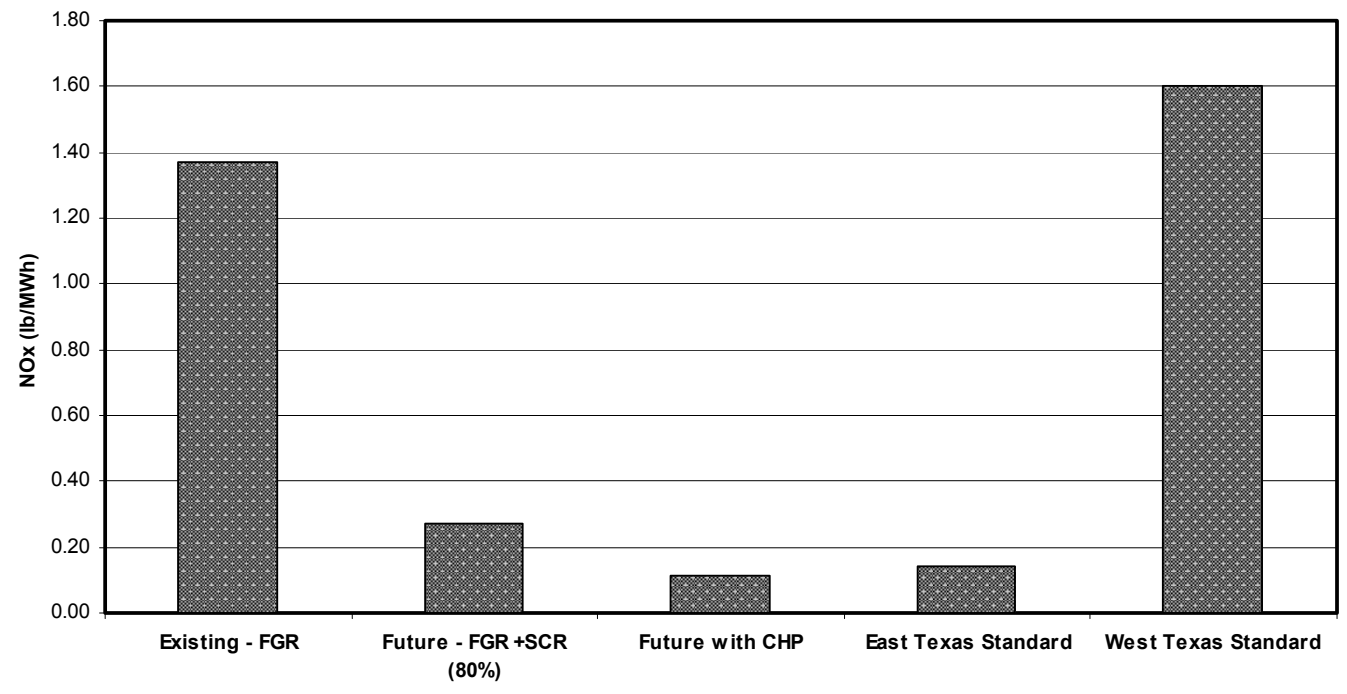

Figure 14: Biomass Combustion - Potential for NOx Reduction 


\section{Life Cycle Analysis}

The generation of electricity, and the consumption of energy in general, results in consequences to the environment. Using renewable resources may result in less environmental damage, but to what degree, and with what trade-offs? Life cycle assessment studies have been conducted on various power generating options in order to better understand the environmental benefits and drawbacks of each technology. Material and energy balances were used to quantify the emissions, energy use, and resource consumption of each process required for the power plant to operate. These include feedstock procurement (mining coal, extracting natural gas, growing dedicated biomass, collecting residue biomass), transportation, manufacture of equipment and intermediate materials (e.g., fertilizers, limestone), construction of the power plant, decommissioning, and any necessary waste disposal.

The systems studied were:

- $\quad$ a biomass-fired integrated gasification combined cycle (IGCC) system using a biomass energy crop (hybrid poplar)

- $\quad$ a direct-fired biomass power plant using biomass residue (urban, primarily)

- a pulverized coal boiler with steam cycle, representing the average for coal-fired power plants in the U.S. today

- $\quad$ a system cofiring biomass residue with coal ( $15 \%$ by heat input will be presented here)

- a natural gas combined cycle power plant.

The total energy consumed by each system includes the fuel energy consumed plus the energy contained in raw and intermediate materials that are consumed by the systems. The total system energy consumption by each system is shown in Table 11 .

Table 11: Total System Energy consumption

\begin{tabular}{|lc|}
\hline \multicolumn{1}{|c|}{ System } & $\begin{array}{c}\text { Total energy consumed } \\
(\mathrm{kJ} / \mathrm{kWh})\end{array}$ \\
Biomass-fired IGCC using hybrid poplar & 231 \\
Direct-fired biomass power plant using biomass residue & 125 \\
Average coal & 12,575 \\
Biomass / coal cofiring (15\% by heat input) & 10,118 \\
Natural gas IGCC & 8,377 \\
\hline
\end{tabular}

To examine operations that consume the largest quantities of energy within each system, two energy measurement parameters were defined. First, the energy delivered to the grid divided by the total fossilderived energy consumed by each system was calculated. This measure, known as the net energy ratio, is useful for assessing how much energy is generated for each unit of fossil fuel consumed. The other measure, the external energy ratio, is defined to be the energy delivered to the grid divided by the total non-feedstock energy to the power plant. That is, the energy contained in the coal and natural gas used at the fossil-based power plants is excluded. The external energy ratio assesses how much energy is generated for each unit of upstream energy consumed. Figure 15 shows the energy results for each case studied. 


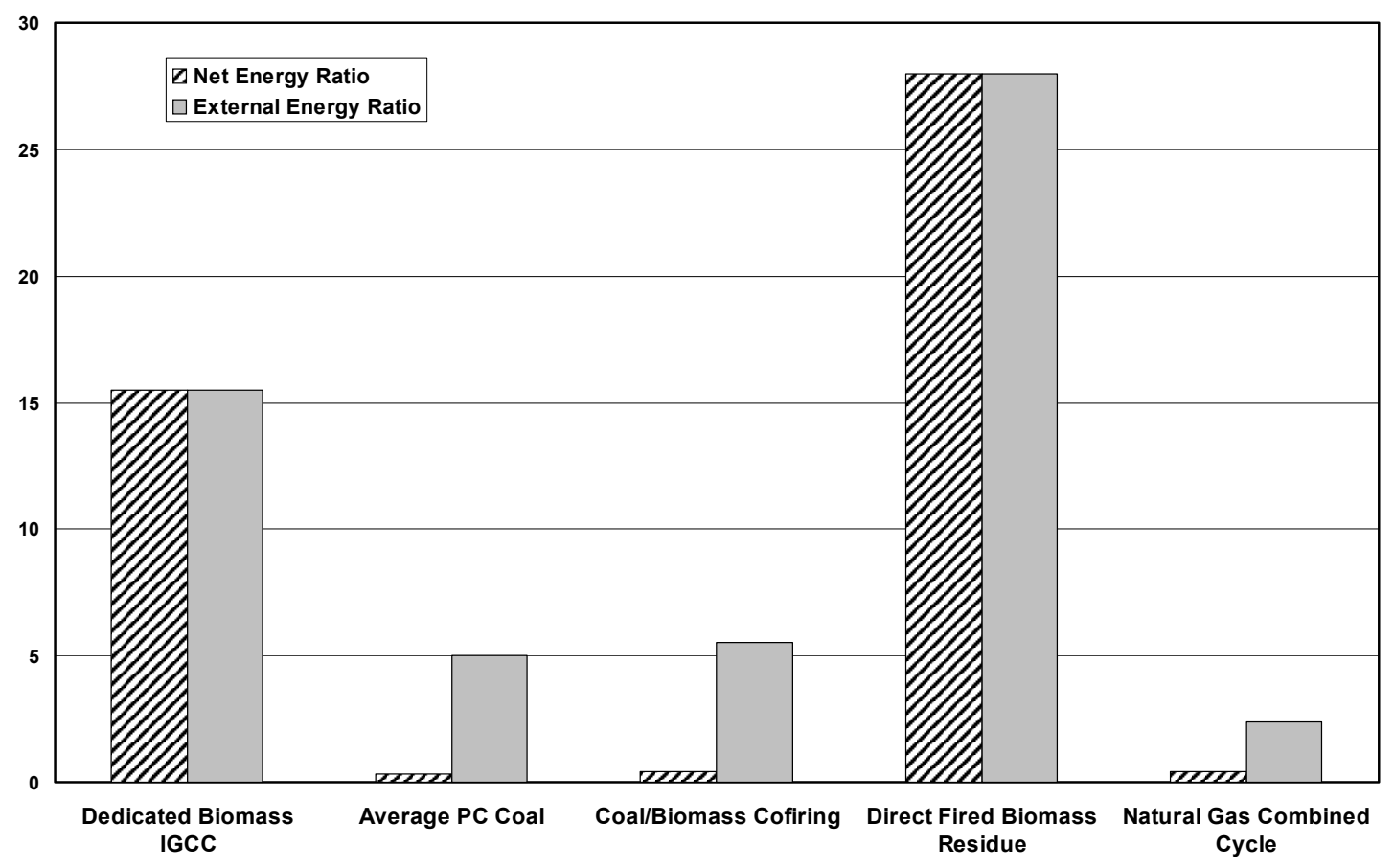

Figure 15 : Life Cycle Energy Balance

As expected, the biomass-only plants consume less energy overall, since the consumption of nonrenewable coal and natural gas at the fossil plants results in net energy balances of less than one. The direct-fired biomass residue case delivers the most amount of electricity per unit of energy consumed. This is because the energy used to provide a usable residue biomass to the plant is fairly low. Despite its higher plant efficiency, the biomass IGCC plant has a lower net energy balance than the direct-fired plant because a significant amount of energy was required to grow the biomass as a dedicated crop. Resource limitations, however, may necessitate the use of energy crops in the future. Cofiring biomass with coal slightly increases the energy ratios over those for the coal-only case, even though the plant efficiency was derated by 0.9 percentage points.

Figure 16 shows the net emissions of greenhouse gases, using the 100-year values from the Intergovernmental Panel on Climate Change. $\mathrm{CO}_{2}, \mathrm{CH}_{4}$, and $\mathrm{N}_{2} \mathrm{O}$ were quantified for these studies. The biomass IGCC system has a much lower global warming potential than the fossil systems because of the absorption of $\mathrm{CO}_{2}$ during the biomass growth cycle. The direct-fired biomass system has a highly negative rate of greenhouse gas emissions because of the avoided methane generation associated with biomass decomposition that would have occurred had the residue not been used at the power plant. 


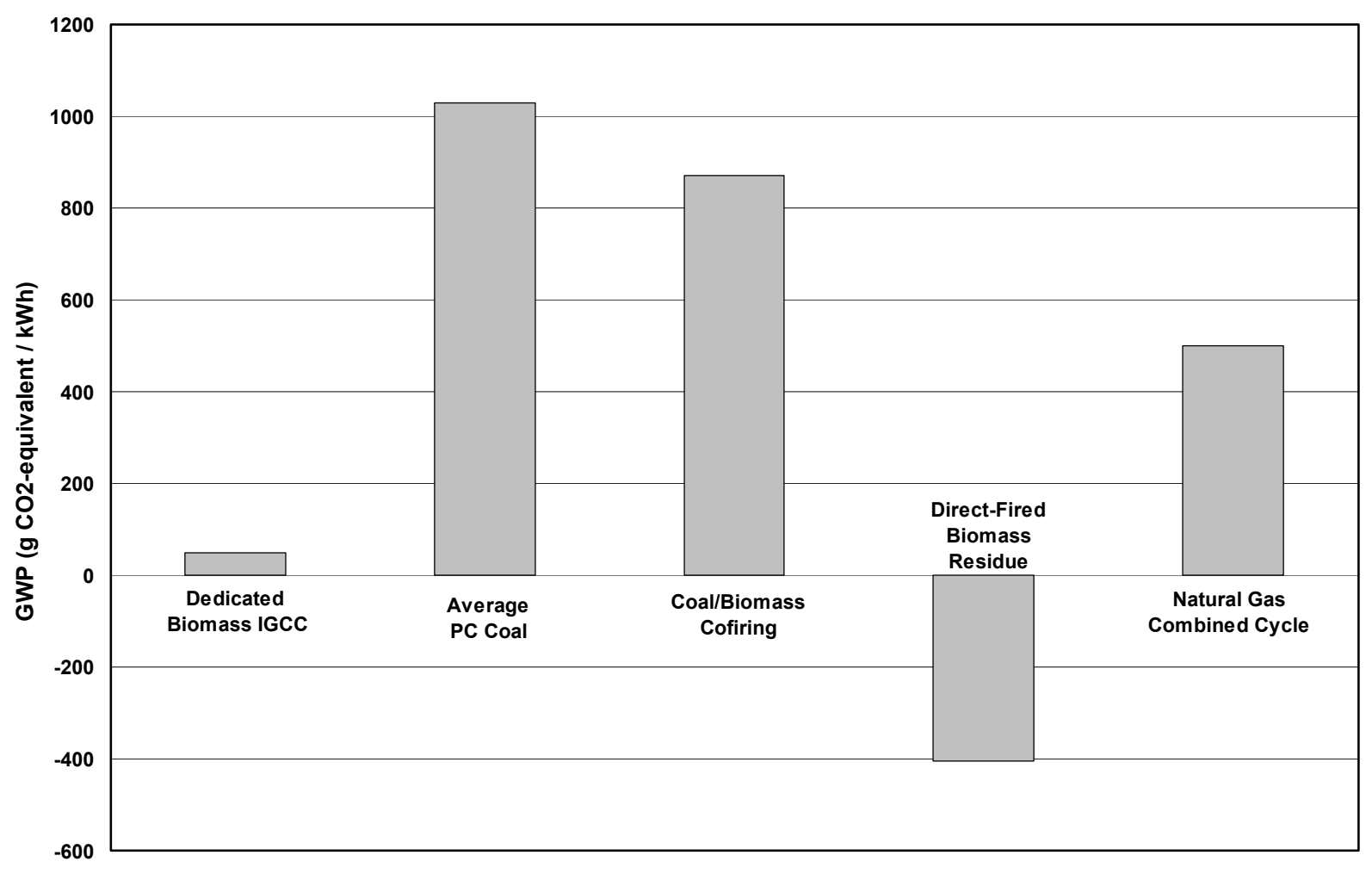

Figure 16: Net Life Cycle Greenhouse Gas Emissions

The life cycle assessment studies has permitted the determination of where biomass power systems reduce the environmental burden associated with power generation. The key comparative results can be summarized as follows:

- The GWP of generating electricity using a dedicated energy crop in an IGCC system is $4.7 \%$ of that of an average U.S. coal power system.

- $\quad$ Cofiring residue biomass at $15 \%$ by heat input reduces the greenhouse gas emissions and net energy consumption of the average coal system by $18 \%$ and $12 \%$, respectively.

- The life cycle energy balances of the coal and natural gas systems are significantly lower than those of the biomass systems because of the consumption of non-renewable resources.

- Not counting the coal and natural gas consumed at the power plants in these systems, the net energy balance is still lower than that of the biomass systems because of energy used in processes related to flue gas clean-up, transportation, and natural gas extraction and coal mining.

- $\quad$ The biomass systems produce very low levels of particulates, $\mathrm{NO}_{\mathrm{x}}$, and $\mathrm{SO}_{\mathrm{x}}$ compared to the fossil systems.

- $\quad$ System methane emissions are negative when residue biomass is used because of avoided decomposition emissions.

- $\quad$ The biomass systems consume very small quantities of natural resources compared to the fossil systems.

- $\quad$ Other than natural gas, the natural gas IGCC consumes almost no resources. 
These results demonstrate quite clearly that, overall, biomass power provides significant environmental benefits over conventional fossil-based power systems. In particular, biomass systems can significantly reduce the amount of greenhouse gases that are produced, per kWh of electricity generated. Additionally, because the biomass systems use renewable energy instead of non-renewable fossil fuels, they consume very small quantities of natural resources and have a positive net energy balance. Cofiring biomass with coal offers us an opportunity to reduce the environmental burdens associated with the coal-fired power systems that currently generate over half of the electricity in the United States. Finally, by reducing $\mathrm{NO}_{\mathrm{x}}$, $\mathrm{SO}_{2}$, and particulates, biomass power can improve local air quality.

\section{Policy}

U.S. government policies are used to advance energy strategies such as energy security and environmental quality. In the case of renewable energy, and bioenergy in particular, a variety of policies have been implemented - research, development, and demonstration of new technologies, financial incentives, and regulatory mandates - to advance the use of renewables in the energy marketplace and thus realize the benefits of renewable energy. Many of the benefits of renewable energy are not captured in the traditional marketplace economics. Government policies are a means of converting non-economic benefits to an economic basis, often referred to as "internalizing" of "externalities." This may be accomplished by supporting the research, development, and demonstration of new technologies that are not funded by industry because of projected high costs or long development time lines. To facilitate the introduction and market penetration of renewable technologies the government may establish financial incentives such as tax credits for new technology or additional taxes on existing technology to make the product economically competitive. The government may also mandate the use of renewable energy or products through regulatory actions that override market economics. A Renewable Portfolio Standard that requires a given percentage of renewable generation of electricity is an example of regulatory policy. This report briefly reviews the pertinent Federal government policies.

\section{Research, Development, and Demonstration/Deployment}

Biomass research, development, and demonstration/deployment (RD\&D) of power, heat, fuels, and chemicals production technologies has been the subject of United States government programs since the early 1970s. By 1977, all energy RD\&D activities were consolidated in a new cabinet, the U.S. Department of Energy. This department had then, and has now, multiple missions, including energy, energy security, defense-related activities such as nuclear weapons development and production, their safety and security, and advancement of the related science and technology (USDOE 2001).

Biomass and bioenergy funding from the USDOE can be framed in the context of the overall energy RD\&D appropriations since 1978. A comparison of the major energy producing expenditures is shown in Figure 17, where funding for each of the technologies is in the order:

nuclear $>>$ coal $>$ renewables $>>$ oil, gas, and shale.

Renewable RD\&D investments over this period have been one-quarter to one-third of those in the nuclear area. Within the renewable energy technologies, Figure 18, biomass and biofuels represent $12 \%$ of the overall investment (1978-2000) or $\$ 1.2$ billion (2000\$). Additional biomass investments are found in the industrial activities funded under energy efficiency such as pulp and paper, agriculture, alternative feedstocks to chemicals, etc. (see Figure 19). 


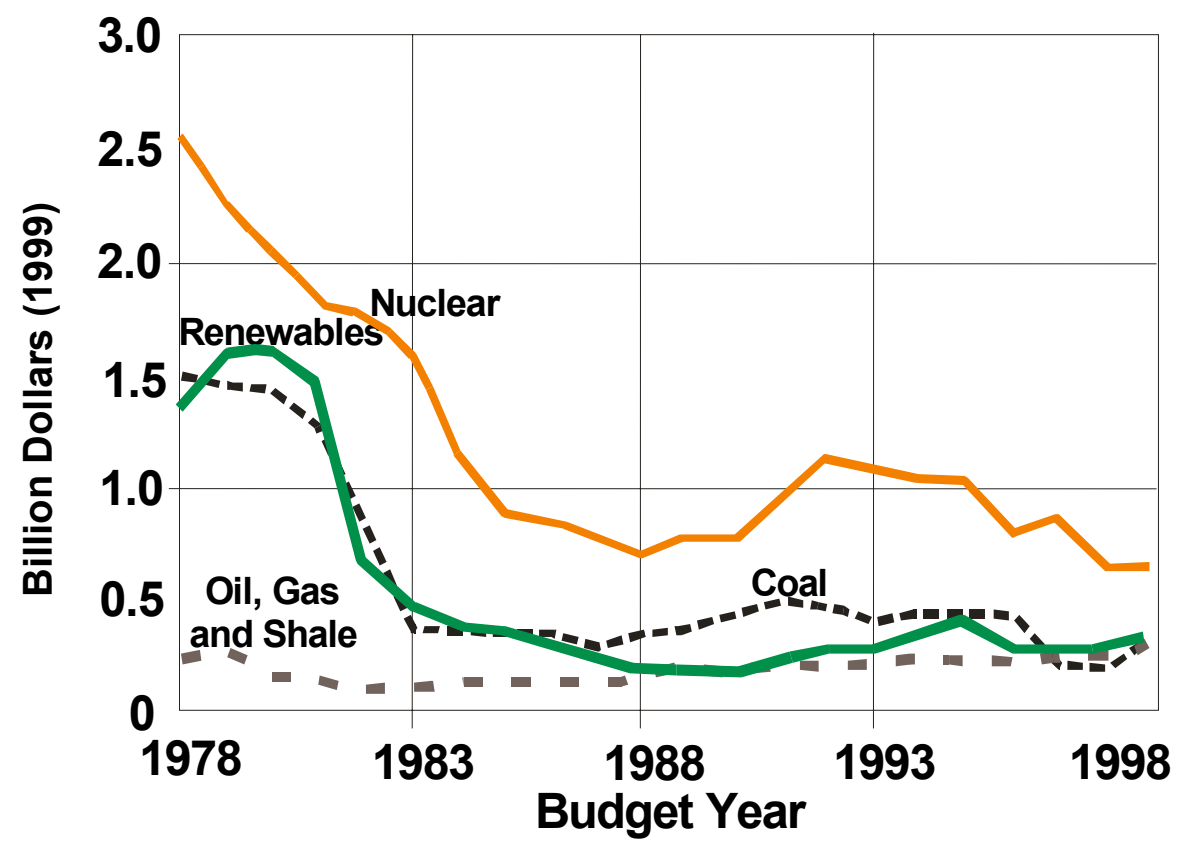

Figure 17: United States Appropriations for Energy R\&D 1978 - 1998 


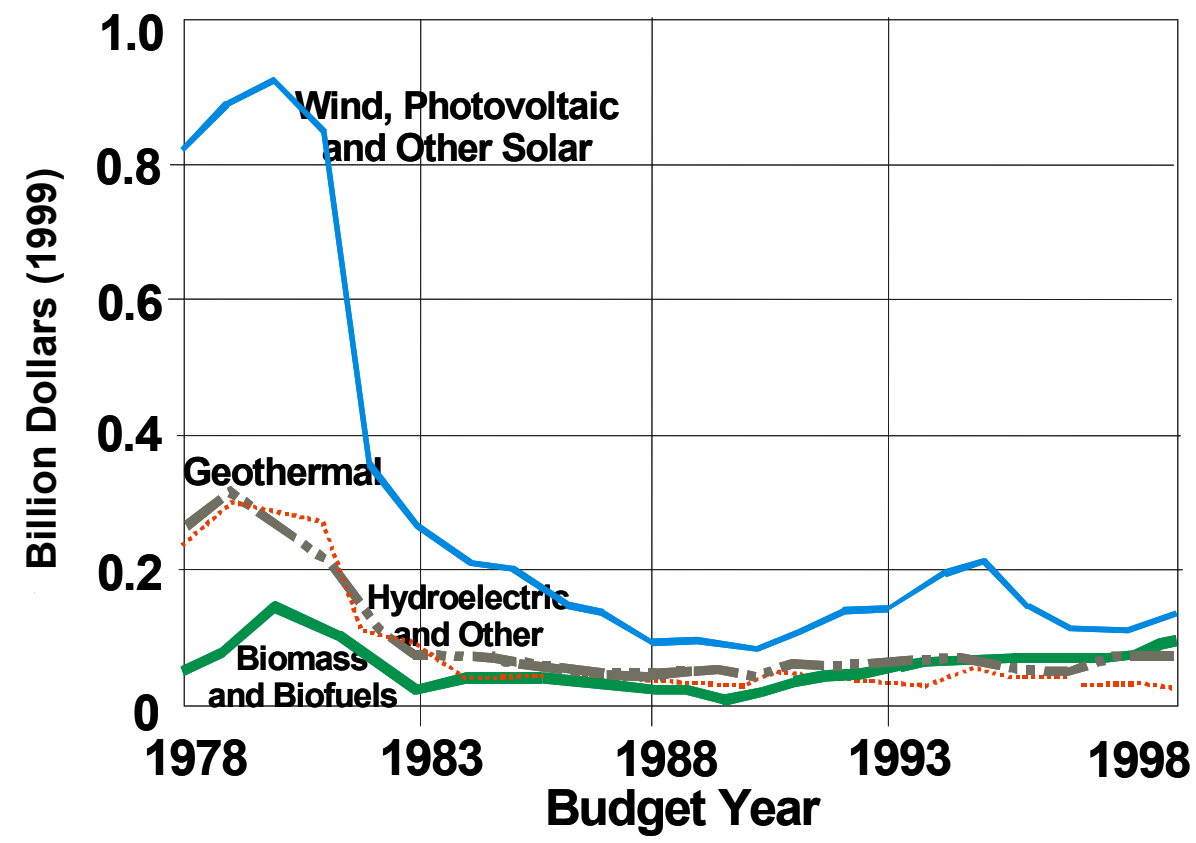

Figure 18: United States Appropriations for Renewables R\&D 1978 - 1998 


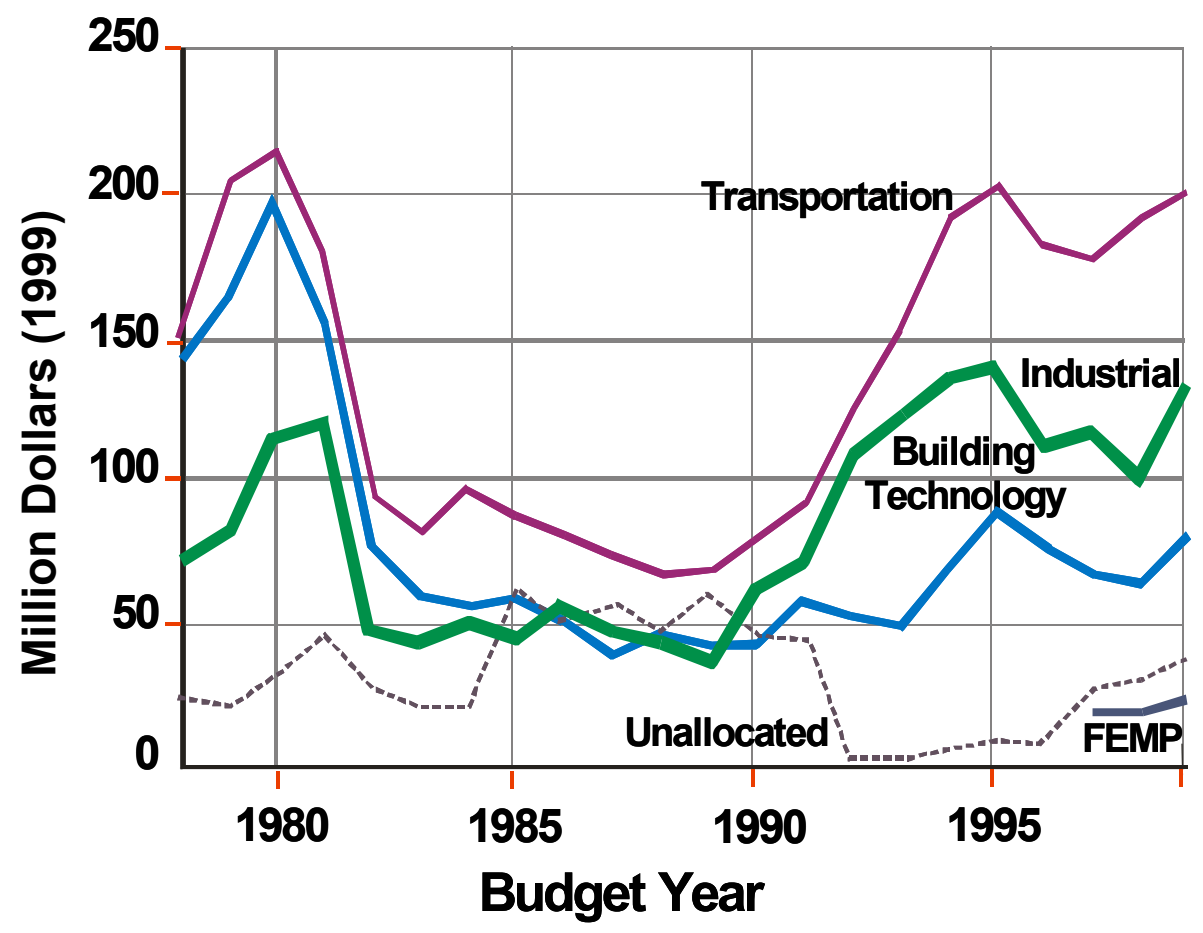

Figure 19: United States Appropriations for Energy Efficiency R\&D 1978 - 1998

A baseline (essentially a single snapshot) inventory of the overall government funding for bioenergy and biobased products for the United States federal government was prepared for fiscal year 1998 (Chum, Elam et al. 2000). In that year the U.S. federal government invested $\$ 253$ million in RD\&D activities, including investments in basic research at the DOE Office of Science and at the Ntional Science Foundation. Of the $\$ 253$ million, $\$ 153$ million were devoted to bioenergy. Approximately $90 \%$ of the total bioenergy and biobased products amount, nearly $\$ 230$ million (2000\$), was appropriated through DOE and USDA programs. Other agencies - the NSF, EPA, and the Department of Commerce (Advanced Technology Program) - funded specific activities in support of these areas. Figures Policies $4 \mathrm{a}$, and $4 \mathrm{~b}$ illustrate the portfolio of technical areas and funding allocations by Federal activity.

In fiscal year 2001, the government investment in RD\&D at DOE and USDA was \$239 million. The total R\&D investment level by these two departments was similar to the previous numbers, but there were major changes in emphasis and scope. These totals do not include R\&D investments at the NSF on the Plant Genome Research Program. The NSF plant genome activities began in 1998, and a portion of the \$25 million annual budget is certainly applicable to biomass activities. The NSF also funds bioprocessing, metabolic engineering, separations technologies, fermentation and enzyme-catalyzed systems, chemistry, materials, and engineering programs, which include biobased products and bioenergy. In fiscal year 2001, the EPA invested $\$ 7$ million in biomass-related activities, according to a report to Congress on Biomass Research and Development Act of 2000 (USDA/USDOE 2001). 


\section{Incentives}

The major Federal legislation on financial incentives for renewable energy and renewable transportation fuels has been structured as tax credits and production incentive payments. For renewable energy, tax credits for purchases of renewable energy equipment were aimed at both the residential and business sectors. Accelerated depreciation of renewable energy equipment and production incentives were aimed at investors. From 1978 through 1998, similar types of tax credits have been in existence. Over time, the various laws have usually expanded the technologies covered, increased the credit amount, or extended the time period.

Two new types of financial incentives were introduced as part of the Energy Policy Act of 1992 (EPACT) - a production tax credit (PTC) and a renewable energy production incentive (REPI). The PTC is a 1.5 cents-per- kilowatthour ( $\mathrm{kWh}$ ) payment, payable for 10 years, to private investors as well as to investor-owned electric utilities for electricity from wind and closed-loop biomass facilities. The PTC is also known as the Section 45 tax credit, and was modified in 1999 to include chicken litter as well as closed-loop biomass. Closed-loop biomass is defined as biomass grown and harvested specifically for energy purposes. As far as is known today, to date no organization has applied for the PTC for closedloop biomass. The REPI provides a 1.5 cents-per-kWh incentive, subject to annual congressional appropriations, for generation from biomass (except municipal solid waste), geothermal (except dry steam), wind and solar from tax-exempt publicly owned utilities, local and county governments, and rural cooperatives.

\section{Regulatory}

The Public Utility Regulatory Policies Act of 1978 (PURPA) was the most significant section of the National Energy Act in fostering the development of facilities to generate electricity from renewable energy sources. However, with the electric power industry challenging its legality and implementation issues, the broad application of PURPA did not occur until after the legality of PURPA was upheld in 1981. PURPA opened the door to competition in the U.S. electricity supply market by requiring utilities to buy electricity from qualifying facilities (QFs). QFs are defined as nonutility facilities that produce electric power using cogeneration technology, or power plants no greater than 80 megawatts of capacity that use renewable energy sources. There is no size restriction for cogeneration plants; however, at least 5 percent of the energy output from a qualifying cogeneration facility must be dedicated to "useful" thermal applications. Under PURPA, utilities are required to purchase electricity from QFs at the utilities' "avoided cost."

PURPA established a new class of generator, qualifying facilities (QF), that afforded cogenerators and certain renewable generators the opportunity to sell electricity to electric utilities at the utility's avoided cost rates. These facilities were also granted tax benefits described in, which lowered their overall costs. PURPA's QF status applied to existing as well as new projects. Together, by year end 1998, existing and new projects totaled 12,658 megawatts of QF renewable capacity (Table 3). Of this, two-thirds (8,219 megawatts) of QF capacity was biomass. Some of these biomass QFs, however, were not "new" facilities, but rather had gone into commercial operation prior to PURPA. PURPA enabled these facilities to connect to the grid, if they chose to become QFs, and sell any generation beyond their own use at avoided cost rates. 


\begin{tabular}{|c|c|c|}
\hline Fuel Source & $\begin{array}{l}\text { Nameplate Capacity } \\
\text { (megawatts) }\end{array}$ & $\begin{array}{c}\text { Gross Generation } \\
\text { (thousand megawatthours) }\end{array}$ \\
\hline Biomass & 8,219 & 45,032 \\
\hline Geothermal & 1,449 & 9,882 \\
\hline Hydroelectric $^{\text {a }}$ & 1,263 & 5,756 \\
\hline Wind & 1,373 & 2,568 \\
\hline Solar Thermal & 340 & 876 \\
\hline Photovoltaic & 14 & 11 \\
\hline Total Renewable QF & 12,658 & 64,126 \\
\hline Total QF, All Sources & 60,384 & 327,977 \\
\hline Total Nonutility, All Sources & 98,085 & 421,364 \\
\hline
\end{tabular}

Utility wholesale power purchases from other utilities, which are more often made on a mutually agreeable economic basis between utilities and may be regarded as reflecting "wholesale" prices, averaged 3.53 cents per $\mathrm{kWh}$ nationwide in 1995. Although EIA has not attempted to estimate the cost of PURPA directly, it has examined the prices that utilities paid in 1995 to purchase power from nonutilities and, in particular, PURPA QF nonutilities using renewable resources. The average price utilities paid all nonutilities was 6.31 cents per $\mathrm{kWh}$ nationwide, considerably higher than the average wholesale price. Higher still was the price utilities paid nonutilities for renewable-based electricity. Utilities paid an average of 9.05 cents per kWh for nearly 42,800 million $\mathrm{kWh}$ of power from renewable QFs in 1995, compared with just 5.17 cents per $\mathrm{kWh}$ for 3,300 million $\mathrm{kWh}$ of power from non-QF renewables. This difference was even more extreme in California, where the renewable QF/non-QF purchased power costs were 12.79 and 3.33 cents per kWh, respectively. All non-QF purchases of renewable energy, however, were from hydropower facilities, the lowest cost renewable resource-and the lowest cost of all electricity resources. In analyzing these data, the reader should bear in mind that by 1995, many of the original PURPA power purchase contracts between utilities and nonutilities had expired. Therefore, the data reflect a mixture of the original avoided cost contracts and newer contracts. 


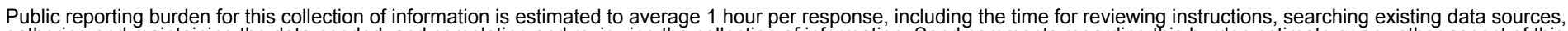

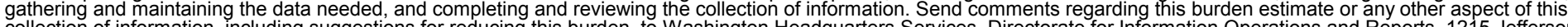

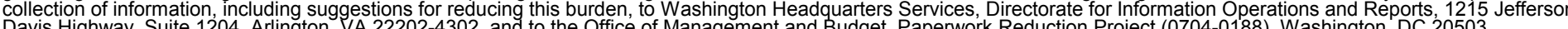

Davis Highway, Suite 1204, Arlington, VA 22202-4302, and to the Office of Management and Budget, Paperwork Reduction Project (0704-0188), Washington, DC 20503.
1. AGENCY USE ONLY (Leave blank)
2. REPORT DATE
3. REPORT TYPE AND DATES COVERED
April 2003
Technical Report

4. TITLE AND SUBTITLE

Highlights of the Biopower Assessment: State of the Industry and the Technology

5. FUNDING NUMBERS

6. $\operatorname{AUTHOR}(\mathrm{S})$

BBB3.6110

R.L. Bain, W.A. Amos, M. Downing, R.L. Perlack

7. PERFORMING ORGANIZATION NAME(S) AND ADDRESS(ES)

National Renewable Energy Laboratory

1617 Cole Blvd.

Golden, CO 80401-3393 REPORT NUMBER

NREL/TP-510-33502

9. SPONSORING/MONITORING AGENCY NAME(S) AND ADDRESS(ES)

10. SPONSORING/MONITORING AGENCY REPORT NUMBER

11. SUPPLEMENTARY NOTES

12a. DISTRIBUTION/AVAILABILITY STATEMENT

National Technical Information Service

12b. DISTRIBUTION CODE

U.S. Department of Commerce

5285 Port Royal Road

Springfield, VA 22161

13. ABSTRACT (Maximum 200 words)

This report summarizes the findings of the Biopower Technical Assessment, which reviews the state of the biopower industry and the technology for producing electricity and heat from biomass.

14. SUBJECT TERMS

biopower; biomass energy industry; biomass conversion technologies

15. NUMBER OF PAGES

16. PRICE CODE

17. SECURITY CLASSIFICATION OF REPORT

Unclassified
18. SECURITY CLASSIFICATION OF THIS PAGE Unclassified
19. SECURITY CLASSIFICATION OF ABSTRACT

Unclassified
20. LIMITATION OF ABSTRACT

UL 